Hydrol. Earth Syst. Sci. Discuss., https://doi.org/10.5194/hess-2017-761

Manuscript under review for journal Hydrol. Earth Syst. Sci.

Discussion started: 9 January 2018

\title{
Subsurface hydrological connectivity of vegetated slopes: a new modeling approach
}

\author{
Massimiliano Schwarz ${ }^{1,2}$, Filippo Giadrossich ${ }^{3}$, Peter Lüscher ${ }^{1}$, and Peter F. Germann ${ }^{4}$ \\ ${ }^{1}$ Swiss Federal Research Institute for forest, snow and landscape, WSL, Birmensdorf, Switzerland \\ ${ }^{2}$ Bern University of Applied Sciences, Zollikofen, Switzerland \\ ${ }^{3}$ Department of Agriculture, University of Sassari, Sassari, Italy \\ ${ }^{4}$ Soil Science Section, Department of Geography, University of Bern, Bern, Switzerland \\ Correspondence to: Massimiliano Schwarz: masismiliano.schwarz@bfh.ch
}

\begin{abstract}
Vegetation strongly influences the hydrology of hillslopes through different processes that may be important for the mitigation of flood risks. The complicated interactions of mechanisms that contribute to the formation of runoff at different spatial and temporal scales represent a big challenge for catchment hydrology. However, it is recognized that storage capacity and infiltration are one of the most important processes positively influenced by vegetation. Moreover, numerical studies

5 have discussed the importance of preferential subsurface flow as dominant processes contributing to fast runoff in mountain catchments. While, previous studies have shown the importance of bedrock topography on the connectivity and drainage of shallow soil mantled hillslopes, no studies discussed the role of heterogeneous root distribution on the drainage of hillslope with stagnic soils so far. In this work we present a conceptual model that aims to link modelling approaches of root distribution combined to hydrological modelling of preferential flow, and the quantification of hydrological connectivity of forest hillslopes.
\end{abstract} We use a spatial distributed root distribution model to calculate the number of fine roots based on the structure of forest cover (tree position and dimension). The results of root distribution are used as input parameter for the quantification of preferential flow patches using a numerical approach. Finally, we use the spatial distributed values of preferential flow to calculate the hydrological connectivity of a vegetated hillslope considering topography and soil profile characteristics. The new proposed framework is calibrated through field experiments at the soil profile scale, and the first results of the numerical simulations considering different combination of parameters are discussed in the context of protection forests mitigation effects against flood risks.

\section{Introduction}

Protection forests management is considered an important prevention measure in mitigating flood risks. Long praxis experience gave evidence of those effects, but the quantification of the processes that lead to these effects are far from well understood. In some countries, protection forests are subject to national management programs and their flood-mitigation effects are recognized in the national guidelines, which consider both soil types and stand characteristics as important criteria for the estimation of the effective protective effects of forests. However, the guidelines include only the water storage capacity as a physical 
Hydrol. Earth Syst. Sci. Discuss., https://doi.org/10.5194/hess-2017-761

Manuscript under review for journal Hydrol. Earth Syst. Sci.

Discussion started: 9 January 2018

parameter, while methods for an holistic quantification of the forest's protective function are poorly developed and frequently subject of controversy.

\subsection{Hydrological processes, forests effects and flooding}

Sufficient literature data suggest that processes such as interception (0-5 $\mathrm{mm} \max )$ and ET (0-2 $\mathrm{mm} / \mathrm{h}$ ) may be positively influ-

5 enced by the presence of vegetation. However, the contribution of these effects for the mitigation of floods during extraordinary short and intense rainfalls is relative low. In contrast, the influence of vegetation on the interception and ET in the long term may have considerable influence in determining the pre-event conditions and thus the hydrological response of a watershed. The effects of vegetation on infiltration, retention capacity, percolation and drainage are strongly related to the characteristics of soil type and vadose-zone biological activity (including root network dynamics). Previous studies have shown that infiltration is increased by root density (Lange et al., 2012), and water retention capacity of soil is increased by reforestation (Wahren et al., 2012). Moreover, percolation and drainage of rooted soil is influenced by the spatial distribution of preferential flow paths (Sidle et al., 2001; Bogner et al., 2010). The above listed quantity of vegetation effects on hydrological processes may be put in the context considering extreme rainfall events with a return time of 100 years; for instance, in the swiss alps, such events have 45-90 $\mathrm{mm}$ precipitations in 1 hour, or $120-300 \mathrm{~mm}$ in 24 hours.

On forested hillslopes, lateral preferential flow is considered a dominant process contribution to runoff during intense rainfall events. Recent studies and field observations indicate that roots increase the hydrological efficiency of preferential-flow path networks, directly and indirectly (Lin, 2012). This leads to the hypothesis that root spatial distributions at hillslopes, controlled principally by the structure of vegetation cover and the species composition, strongly influence the network of preferential flow paths, and ultimately the water fluxes and drainage efficiency of vegetated slopes.

The objective of this work is to analyze the influence of root distribution at the soil profile scale on lateral preferential flow, and conceptualize the documented runoff behavior in a numerical model to quantify and upscale the impact of preferential-flow paths connectivity on the hydrological response of vegetated hillslopes.

\section{Material and Methods}

\subsection{Study area}

25 The study area is situated in the northern foothills of the Swiss alps (canton of Bern) in the Gantrisch region at an elevation of 1220 m.a.s.l., on a N-W exposed hillslope ( $46^{\circ} 45.241$ / E $7^{\circ} 22.216$ ). The climate is atlantic, the mean annual precipitation is between 1100 and $2000 \mathrm{~mm} /$ year, and the mean annual temperature are between 7 and $5.5^{\circ} \mathrm{C}$. The geology is dominated by molasse in the deeper layers and by flysch-schist in the upper geological layers. The pedological characteristics of each soil profile were described following a standard procedure. Soil bulk density was measured collecting three undisturbed soil sample per soil horizons in each profile. The volume of the cylinders used to collect the soil samples have 1 liter volume and $0.1 \mathrm{~m}$ height. Soil samples were dried for $48 \mathrm{~h}$ at $105^{\circ} \mathrm{C}$. The $\mathrm{pH}$ range between 3 in the upper part of the profiles and 5 in the 
Hydrol. Earth Syst. Sci. Discuss., https://doi.org/10.5194/hess-2017-761

Manuscript under review for journal Hydrol. Earth Syst. Sci.

Discussion started: 9 January 2018

(c) Author(s) 2018. CC BY 4.0 License.

(c) (i)
Hydrology and

Earth System

Sciences

Discussions

deeper reduced horizons of the profiles. The texture of soil sample was characterized using the pipette method. Soil texture is characterized by an high content of clay (see Fig. 1) and almost no rock fraction is present in the upper layers of soils. Based on the texture composition, the fine fraction of the soil matrix can be classified as a clay-loam (CL) or a clay $(\mathrm{CH})$, with increasing clay content as function of soil depth.

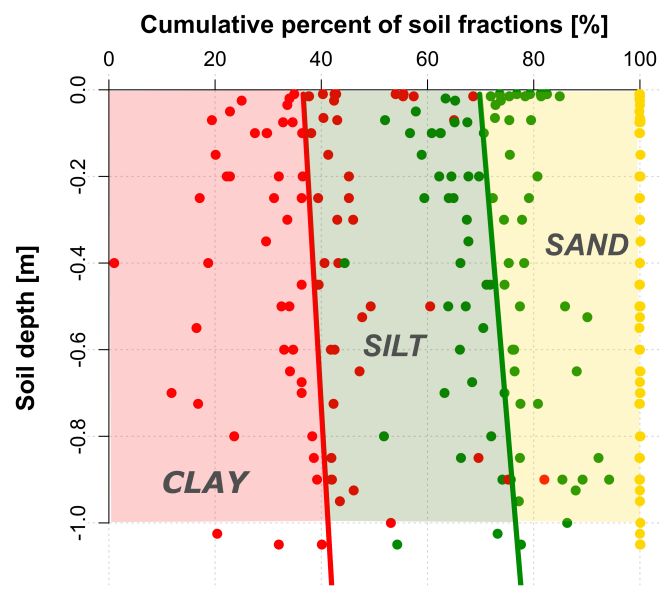

Figure 1. Measured texture fractions of soil samples at different soil depth.

5

The distribution of soil types in the area is heterogeneous and varies in short distances between Gleys, stagnic Cambisols and Cambisols. Beneath soil depths of 0.1-0.6 m hydromorphic attributes such as iron and manganese concretions are found. The layering of the soil horizons is heterogeneously distributed and varies locally in relation to the micro-topography and vegetation (see Fig. 2). In order to compare the distribution of soil diagnostic horizons between soil profiles, horizons type were grouped in 4 classes: class 1 - superficial layers, Ah; class 2 not hydromorphic mineral subsoil, B, Bt, (A)B, AB; class 3 - hydromorphic mineral subsoil, Bcn, BSw, BSd, SB, B(Sw), BGo, ABcn, GoB, BGo; class 4 - wet or permanent saturated subsoil, Go, Gor, Gr(o), Sd, Sw, Gr.

The mean inclination of the hillslope is about $15^{\circ}$, but the complex micro-topography is characterized by a continuous succession of small hollows and ridges. The dominating vegetation cover is composed of spruce (Picea abies) and fir (Abies $a l b a$ ) with a mean height of $25 \mathrm{~m}$. The cover ration reaches about $90 \%$. The phytological comunity is classified as a Vaccinio myrtillii-Abieti-Piceetum typicum. In the past most part of the watershed was covered with meadows and pastures that in context with a reforestation campaign in the middle of the 19th century were extensively afforested with spruce (Picea abies). 
Hydrol. Earth Syst. Sci. Discuss., https://doi.org/10.5194/hess-2017-761

Manuscript under review for journal Hydrol. Earth Syst. Sci.

Discussion started: 9 January 2018

(c) Author(s) 2018. CC BY 4.0 License.
Hydrology and

Earth System

Sciences

Discussions

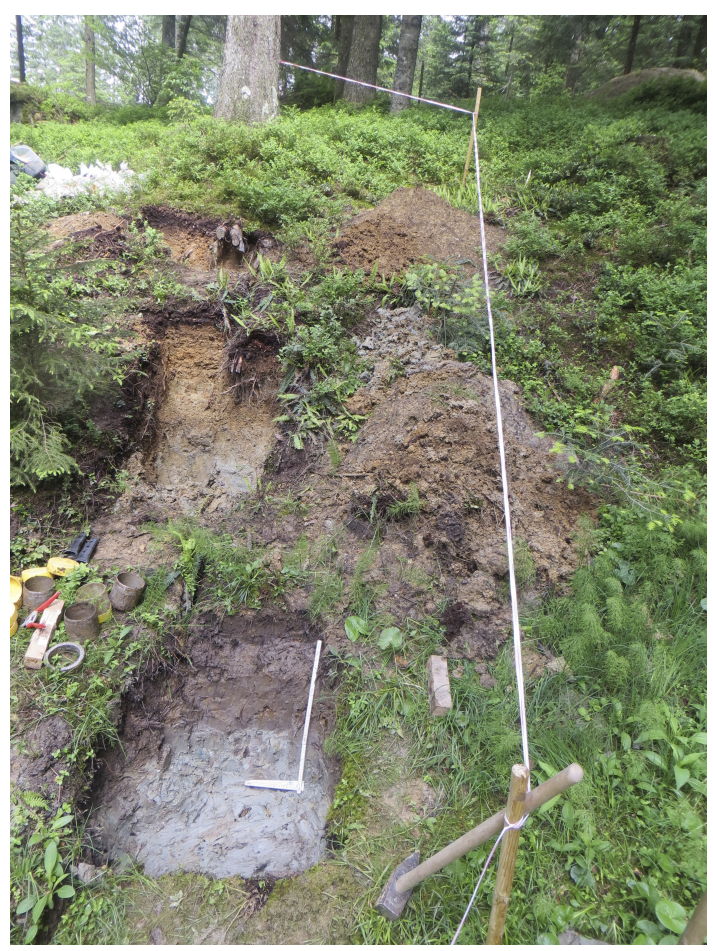

Figure 2. Three analysed soil profiles showing a considerable variation of soil profile characteristics within a short distance. Distance between profiles is $2 \mathrm{~m}$ and length of the meter in the lower profile is about $0.6 \mathrm{~m}$.

\subsection{Modeling framework}

\subsubsection{Preferential flow modeling at the soil profile scale}

In this study we present the building elements of a framework for the upscaling of preferential runoff modeling in forest soils. Previous studies (Lange et al., 2012) have shown that vertical preferential flow in rooted soils can be quantified at the soil 5 profile scale using a dual porosity models (Šimůnek et al., 2003). In this work we combine the Stokes flow approach (Beven and Germann, 2013) for vertical and lateral fluxes, and the mass balance equation in order to couple information about root distribution, variation of soil water content, and runoff behaviors. In the Stokes flow approach, gravity is considered the driving force that has to be balanced by the effect of viscosity in dissipating momentum within water films moving between a sollidwater interface (Germann, 1990). This approach results as a solution of the Navier-Stokes equation for simplified flow regimes, as discussed in Or and Tuller (2000). Preferential flow paths are considered all the meso-, macro-pores or pipes networks that are directly or indirectly influenced by the presence of roots and bioactivity. Previous studies reviewed in Sidle et al. (2001) suggest that lateral preferential flow along forested hillslopes is largely determined by flow in mesopores (0.5-2 mm diameter), since macro-pores and soil pipes rarely results hydrologically connected over significant distances $(>1 \mathrm{~m})$. Similar observation 
Hydrol. Earth Syst. Sci. Discuss., https://doi.org/10.5194/hess-2017-761

Manuscript under review for journal Hydrol. Earth Syst. Sci.

Discussion started: 9 January 2018

(c) Author(s) 2018. CC BY 4.0 License.

(c) (i)
Hydrology and

Earth System

Sciences

Discussions

were done during the experiments in our study area. In the present modeling approach it is distinguished between a immobile $\left(\theta_{\text {fin }}\left[\mathrm{m}^{3} / \mathrm{m}^{3}\right]\right)$ and mobile $\left(w\left[\mathrm{~m}^{3} / \mathrm{m}^{3}\right]\right)$ part of the water content $\left(\theta\left[\mathrm{m}^{3} / \mathrm{m}^{3}\right]\right)$ where

$\theta=\theta_{\text {fin }}+w \quad$ if $\theta>\theta_{\text {fin }}$.

5

The immobile water is composed either by water in the soil matrix, where capillarity force are dominating, or by water stored in disconnected pore features (i.e. blind cracks) at atmospheric pressure. On the other side, in the mobile water, viscous forces are dominating. In accord to other studies (Beven and Germann, 2013; Or and Tuller, 2000) the application of the Stokes flow approach can be considered appropriate only for slow laminar flow characterized by capillary numbers in the range of $10^{-6}$ to $10^{-8}$, bond numbers larger than 0.05 , Reynolds number $<3$, and characteristic lengths larger than $10^{-6} \mathrm{~m}$. Under these conditions it is assumed that equilibrium liquid-vapor interfaces remain stable under relatively slow and laminar flow conditions.

During the wetting phase of a soil profile, the flux of water from macropores and mesopores (mobile water) to the surrounding soil matrix (immobile water) due to a gradient of matrix potential is implemented as a sink term, similar to Di Pietro et al. (2003), using the following equation

$\theta_{f i n}(t)=\theta_{f c, 0}+\frac{\Delta \theta_{f c, t o t}}{e^{\xi / t}}$

where $\Delta \theta_{f c, t o t}$ is the maximal increment of immobile water in a defined time interval, $\xi$ is an empirical shape factor, and $t$ is the time.

Using the Stoke flow formulation it is possible to define the mobile water as

$w=L F$

where $L$ is the unit area of momentum dissipation per unit volume $\left(\left[\mathrm{m}^{2} / \mathrm{m}^{3}\right]\right)$ and $F([\mathrm{~m}])$ is the thickness of the moving water film.

In this approach $L$ is assume to be constant and directly linked to root distribution and soil structure. In each calculation step, the value of $F$ is derived form eq. 3, assuming a "geometrical factor" ( $g f$ ) in order to consider the effect due to the tortuosity and morphology of the pores's surfaces. 
Hydrol. Earth Syst. Sci. Discuss., https://doi.org/10.5194/hess-2017-761

Manuscript under review for journal Hydrol. Earth Syst. Sci.

Discussion started: 9 January 2018

The total volume flux density, $q_{t o t}\left(\left[\mathrm{~s}^{-1}\right]\right)$, of mobile water is derived from the force balance and Newton's shear hypothesis, and it is considered to results from the addition of two vectorial component, a vertical flux $\left(q_{v}\right)$ and a lateral $\left(q_{l a t}\right)$ within the soil profile.

$q_{\text {tot }}=q_{v}+q_{\text {lat }} \quad$ if $\theta_{\text {fin }}<\theta<\theta_{\max }$

5

defining

$q_{v}=c \frac{g}{3 \mu} L F^{3}$

10

and

$q_{\text {lat }}=\frac{\sin (\alpha) g}{3 \mu} L F^{3}$

$q_{t o t}=(c+\sin (\alpha)) \frac{g}{3 \mu} L F^{3}$

where $g\left[\mathrm{~m} \mathrm{~s}^{2}\right]$ is the acceleration due to gravity, $\mu\left(=10^{-6}\right)\left[\mathrm{m} \mathrm{s}^{-1}\right]$ is the kinematic viscosity of water, and $\alpha[\circ]$ is the local slope inclination. Because, the vertical water flux can be limited by low permeable soil layer in the bottom part of a soil profile, such as reduced horizons in stagnic soils, a coefficient $c$ is introduced in order to control the variability of this conditions.

In the case where water content reaches saturation, $\theta_{\max }$, a term for the saturated overland flow is considered in the form

$q_{S O F}=a_{S O F} *\left(\theta-\theta_{\max }\right)^{b_{S O F}} \sin (\alpha)$

where $a_{S O F}$ and $b_{S O F}$ are empirically estimated coefficients.

The equation of water flux can be used to solve the mass balance equation in the form

$\frac{d \theta}{d t}=q_{\text {input }}-q_{\text {tot }}$ 
Hydrol. Earth Syst. Sci. Discuss., https://doi.org/10.5194/hess-2017-761

Manuscript under review for journal Hydrol. Earth Syst. Sci.

Discussion started: 9 January 2018

(c) Author(s) 2018. CC BY 4.0 License.

(c) (i)
Hydrology and

Earth System

Sciences

Discussions

where the previous definition of $q_{t o t}$ implicates a two-dimensional solution (parallel to gravity field and parallel to slope). The sum of the inputs in the system $q_{\text {input }}$ is composed by lateral incoming lateral flow $q_{i n}$ and rainfall input $r$. A time step

5 discretization, indicated by time $t$ [s], is used for the temporal solution of the system of equations in form of a fully explicit finite difference approximation. The temporal evolution of the water content $\theta_{t}$ is expressed as

$\theta_{t}=\theta_{\text {fin }}+w_{t} \quad$ if $\theta>\theta_{\text {fin }}$

with

$10 w_{t}=w_{t-1}+r_{t-1}+q_{i n_{t-1}}-q_{l a t_{t-1}}-q_{v_{t-1}}$

or

$\theta_{t}=\theta_{t-1}+r_{t-1}+q_{i n_{t-1}} \quad$ if $\theta<\theta_{\text {fin }}$

15

assuming that for $\theta<\theta_{\text {fin }}$, there is no water fluxes.

The mobile water flux is assumed to be constantly exposed only to pressures that are at least atmospheric.

Field data provide the parametrical characterization of probability distribution of variables such as:

- Initial volumetric water content, $\theta_{0}$.

20 - Final volumetric water content, that corresponds to the immobile water content, $\theta_{\text {fin }}$.

- Coefficient of vertical water flux, $c$.

\subsubsection{Upscaling approach at the hillslope scale}

The modeling approach at the soil profile scale (ca. $1 \mathrm{~m}$ ) presented in the previous section, is used as building module in an upscaling framework at the hillslope scale. This framework, called the $\mathrm{W}^{2}$ model, is characterized by explicitly considering the spatial variability of the hydrological parameters of soil due to vegetation patterns. In particular the framework focus on the implementation of informations regarding the structure and the species composition of a forest cover in the estimation of punctual root distribution, and from that derives relevant hydrological parameters at the soil profile scale. 
Hydrol. Earth Syst. Sci. Discuss., https://doi.org/10.5194/hess-2017-761

Manuscript under review for journal Hydrol. Earth Syst. Sci.

Discussion started: 9 January 2018

(c) Author(s) 2018. CC BY 4.0 License.
Hydrology and

Earth System

Sciences

Discussions

(c) $\underset{\mathrm{BY}}{(i)}$

The hillslope can be discretised in rectangle or hexagonal grids, where each cell is connected to neighbors cells by "hydrological bonds". The water flow between to neighbor cells is considered to follow the direction with the highest slope gradient. The water flow in each bond is quantified using the Stokes flow equation shown in the previous section.

A validated root-distribution model is used to characterize the spatial distribution of root (Schwarz et al., 2012), from which

5 networks of preferential flow paths are inferred at the scale of the forest stand. The spatial distributions of roots is linked to the distribution of unit area of momentum dissipation per unit volume $L$ through empirical relationships. The results of previous studies suggest a plausible relation between these two parameters (Lange et al., 2012). The estimated spatial distribution of $L$ implemented in the $\mathrm{W}^{2}$ model quantifies the hydrological connectivity of vegetated hillslopes of various forest structures and soil conditions (Fig. 3).

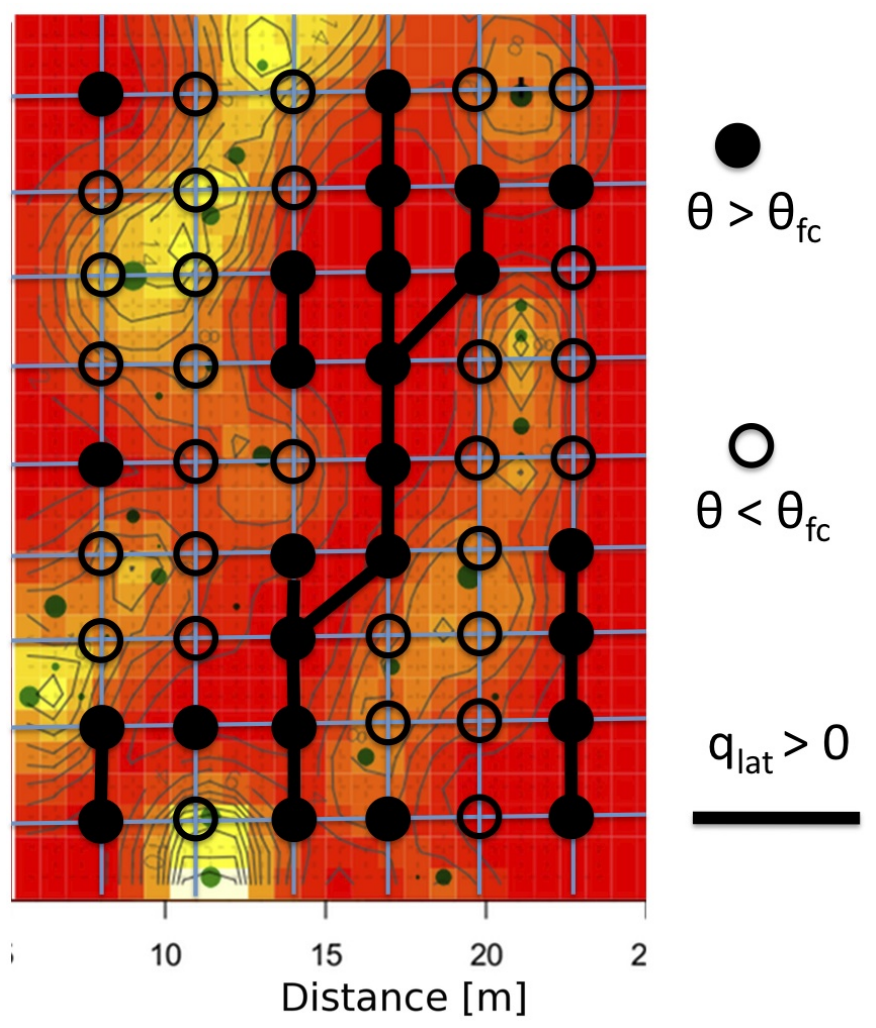

Figure 3. Example of the visualization of the upscaling approach at the hillslope scale. Spatial distribution of roots depend on the forest structure. Red colors indicate low density of roots and yellow colors indicate high density of roots. Green dots indicate position and dimensions of trees. Root distribution is linked to the unit area of momentum dissipation per unit volume $L$.

Connectivity at the hillslope scale is characterised by a percolation theory approach, where occupation probability is assigned stochastically as spatial distribution of initial water content and vertical water flux coefficient. The threshold for the initiation 
Hydrol. Earth Syst. Sci. Discuss., https://doi.org/10.5194/hess-2017-761

Manuscript under review for journal Hydrol. Earth Syst. Sci.

Discussion started: 9 January 2018

of lateral flow in each cell is given by the condition where

$\theta>\theta_{\text {fin }}$

For natural rainfall conditions, canopy and litter interception are implemented in the framework within the values of initial water content, assuming a direct relation between canopy/litter interception capacity distribution and the root distribution.

\section{$5 \quad 2.3 \quad$ Field experiments}

In this study we analyze two series of sprinkling experiments. The first series of "long" experiments was conduct between 2009 and 2011, focusing on the variation of water content during repeated constant rainfall pulses during three days. In the second series of "short" experiments, conducted in summer 2012, water content and lateral runoff were measured during rainfall pulses of different intensity within 8 hours.

\subsection{1 "Long" sprinkling experiments}

The "long" sprinkling experiments aimed to characterize the influence of root distribution on the water content variation within single FDR probes at different soil depth. Previous studies (Lange et al., 2012) used the same type of experiments in order to quantify the influence of root distribution on the infiltration of water analyzing the migration of the wetting fronts between FDR probes at different depths. In these experiments each profiles is irrigated three times at $23 \mathrm{~h}$ interval with an intensity of $70 \mathrm{~mm} / \mathrm{h}$ and a duration of $1 \mathrm{~h}$. These experiments are numerate from P1 to P18.

\section{Water content.}

The method used to measure the variation of volumetric water content was similar to the procedure applied by Lange et al. (2012). The variation of volumetric water content at different time, $t$, and soil depth $Z$, was measured using 5 to 10 sensors (10HS) of the Decagon device (Pullman, USA), with a collecting frequency of $0.017 \mathrm{~Hz}$ (1/60). Dielectric permittivity was converted to volumetric water content using the transfer function of Topp et al. (1980). The position of the sensors within the soil profile was chosen in function of the layering of the genetic horizons, and the wave guides were installed horizontally in the middle of each horizons. The sprinkler device consisted of an aluminum plate $(1 \times 1 \mathrm{~m})$ perforated with 100 holes in a 0.1x0.1 m square pattern. Detailed information about the spindling device can be found in Lange et al. (2012). Figure 4 shows and example of measured water content at three different soil depth in a soil profile during the three days. The lateral inset of the figure show the parameters extrapolated from the third sprinkling experiment in order to characterize the hydrological properties of each soil sample.

\section{Root distribution}

Soil cores for the analysis of the root distribution were collected using a HUMAX soil corer (diameter $0.1 \mathrm{~m}$ ) from the position where the FDR probes where installed. The cores were $0.25 \mathrm{~m}$ long and the soil was left undisturbed. Roots were sorted out and washed in a $1 \mathrm{~mm}$ sieve with tap water. The sorted roots were scanned and analyzed with the software WinRHIZO (V4.1c; Regent Instruments Inc., Quebec, Canada). 
Hydrol. Earth Syst. Sci. Discuss., https://doi.org/10.5194/hess-2017-761

Manuscript under review for journal Hydrol. Earth Syst. Sci.

Discussion started: 9 January 2018

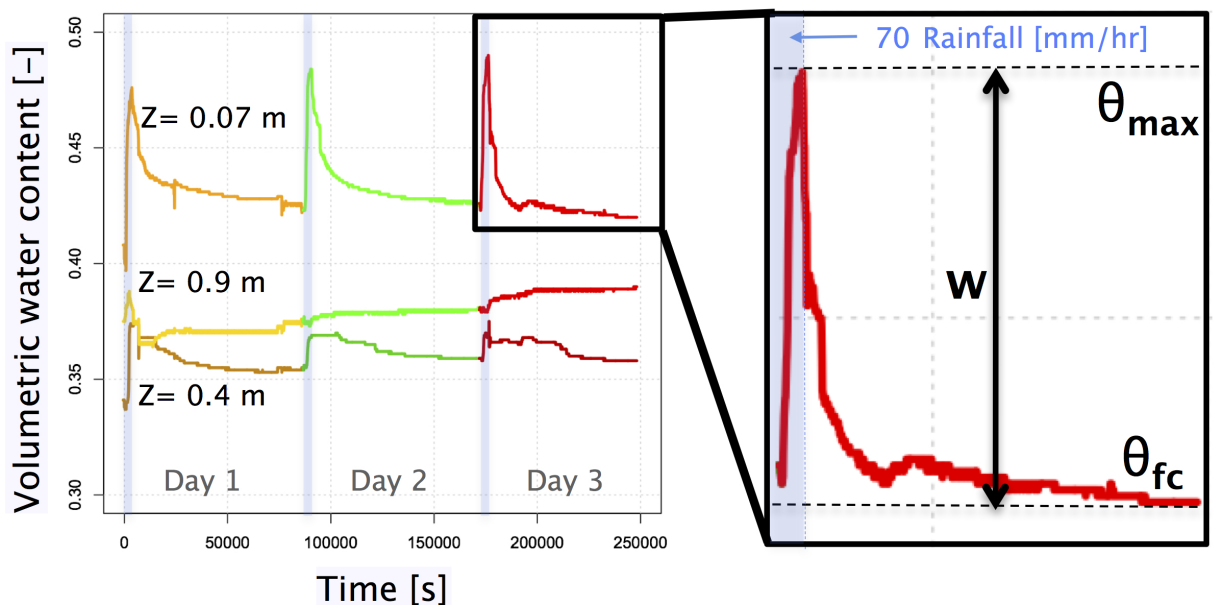

Figure 4. Example of results obtained by long sprinkling experiments. The data show the variation of volumetric water content of three TDR probes at $(0.07,0.4$, and $0.9 \mathrm{~m}$ depth) positioned in a Ah, BS, and Gr horizons, respectively. The three different color indicate the beginning and the end of each consecutive rainfall pulse (1=yellow, $2=$ green, $3=$ red). The lateral inset shows the parameter values obtained from these data.

\subsection{2 "Short" sprinkling experiments}

"Short" sprinkling experiments simulating extreme rainfall events with variable intensity were used to characterize the relationship between preferential lateral subsurface flow and root distributions at soil profile scale $(0.5 \mathrm{~m}$ large and $0.45 \mathrm{~m}$ deep) (Fig. 4). Sprinkling experiments were performed using the same setup as used for the "long" sprinkling experiments. Three 5 levels of rainfall intensity $(70,40$, and $100[\mathrm{~mm} / \mathrm{hr}])$ were applied in order to analyze the response of the soil under different hydrological inputs. The "short" sprinkling were performed systematically at two different distances from tree stem (1.5 and 3.5/5.5 m). These experiments are numerate from P19 to P27. Figure 5 shows the setup of the experiments for the measurement of volumetric water content variation and lateral runoff.

\section{Water content}

Volumetric water content was measured with the same method illustrated for the "long" sprinkling experiments. The main difference is that the FDR probes were placed at regular soil depth $(0.15,0.3$, and $0.45 \mathrm{~m})$. For each experiment 10 FDR probes were used ( 2 at $0.15 \mathrm{~m}, 4$ at 0.3 , and 4 at 0.45 soil depth) with a minimal distance of $0.1 \mathrm{~m}$ between each other. For each experiment the mean value of water content was calculated in order to represent the behavior of the entire volume of considered soil $(0.5 \times 0.5 \times 1 \mathrm{~m})$. From the water content dataset characteristic parameters such as initial water content and final water content were extrapolated as shown in Fig. 6. 
Hydrol. Earth Syst. Sci. Discuss., https://doi.org/10.5194/hess-2017-761

Manuscript under review for journal Hydrol. Earth Syst. Sci.

Discussion started: 9 January 2018

(c) Author(s) 2018. CC BY 4.0 License.

\begin{tabular}{c} 
Hydrology and 을 \\
Earth System \\
Sciences \\
\hline Discussions
\end{tabular}

(c) (i)
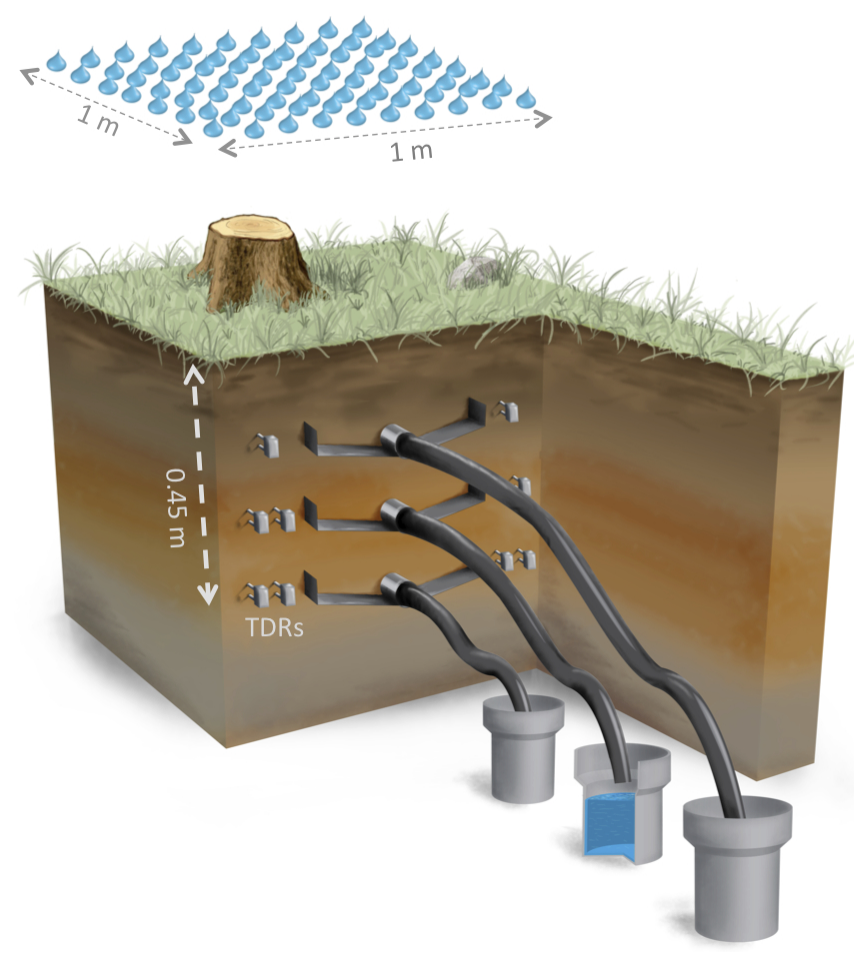

Figure 5. Field setup for the "short" sprinkling experiments.

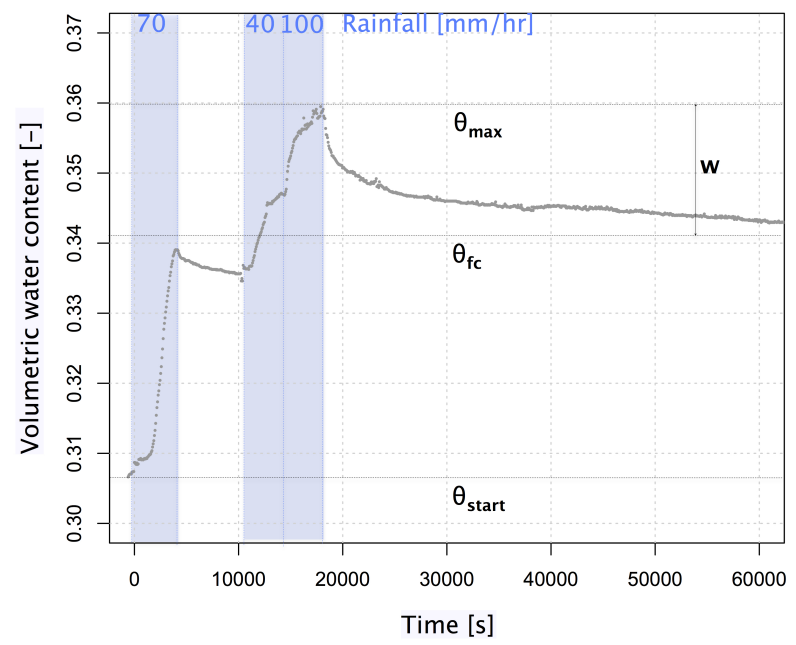

Figure 6. Example of measured changes in volumetric water content during "short" sprinkling experiments.

\section{Runoff}


Hydrol. Earth Syst. Sci. Discuss., https://doi.org/10.5194/hess-2017-761

Manuscript under review for journal Hydrol. Earth Syst. Sci.

Discussion started: 9 January 2018

Lateral flow from the soil profile was collected at three different soil depth $(0.15,0.3$, and $0.45 \mathrm{~m})$ with horizontal metal rills inserted slightly inclined in the soil profile. The flow is concentrated to a drainage hole in the middle of the rill, that is connected to tipping bucket rain gauges by PVC tubes. The tubes were 0.5 to $1 \mathrm{~m}$ long and were "hydrologically connected" before every experiments applying water. The tipping bucket rain gauges collected the runoff data with 5 min interval. The datasets of runoff measurements are used to calibrate the parameter $c$ and $L$ of the model.

\section{Root distribution}

Root distributions are analyzed in terms of root frequencies per root diameter class. The trees for the collection of the data were chosen based on their diameter (DBH), social position within the stand, and aspect. Near each tree, three soil profiles were excavated at three distances from stem $(0.5,1.5$, and $2.5 \mathrm{~m}$ ) (Schwarz et al., 2012). The soil profiles were $0.5 \mathrm{~m}$ width and $0.5 \mathrm{~m}$ deep. The direction where the soil profiles were excavated was chosen minimizing the possible concurrence effects of neighbor trees. Death roots could be distinguished from the live roots on the base of the consistence of the root phloem/xylem and the cortex. Moreover, the species of the roots was determinate based on the bark color/morphology, as well as on root topology. For each soil profile, the diameter (with root cortex) of each root was measured and noted as root frequency vs. root diameter classes. Roots were defined as fine roots with diameter lower or equal than $1.5 \mathrm{~mm}$, and as coarse roots with diameter larger than $1.5 \mathrm{~mm}$. Coarse roots were classified in $1 \mathrm{~mm}$ diameter classes.

\subsection{Fitting model parameters}

Only the " long" sprinkling experiments showing mobile water higher than 0.01, and "short" sprinkling experiments with a significant $(>0.001 \mathrm{~L} / \mathrm{s}$ ) lateral flow (or with a calculated water film thickness $(F)$ larger than $0.5 \mathrm{~mm}$ ) were further analyzed for the calibration of the $\mathrm{W}^{2}$ model parameters. Data from the "long" sprinkling experiments (P1-P18) where used to calibrate the model within single FDR probes considering a representative volume of 1 liter. For each dataset a straight-forward calibration approach was used assuming starting uniform distribution of values for the variable $L$ (contact surface) and $g f$ (geometrical factor). The best combination of values that fits data was defined by minimising the sum of squared error and maximizing the Nash index. Dotty plots were used to visualize and check the gradient of model performance for each combination of parameter values. $10^{4}$ simulations for each dataset fitting where used. A similar approach was used to calibrate the $\mathrm{W}^{2}$ model using the runoff data of the "short" sprinkling experiments (Fig. refautocorrelation). In this case runoff data were used to calibrate the value of $L$. Model fitting with time series of data, such as runoff and water content data, is challenging due to issues of autocorrelation and heteroscedasticity. In the following paragraph the method for the analysis of autocorrelation is summarized.

The general approach used for the calibration follow these steps:

1. Set input rainfall input (rainfall intensity and duration, same as for the sprinkling experiments).

2. Set the values of assumed constant parameters of the model, measured during the experiment, such as initial water content, and residual water content.

3. Run simulation with a range of expected values of $L$ and $g f\left(10^{4}\right.$ times). 
Hydrol. Earth Syst. Sci. Discuss., https://doi.org/10.5194/hess-2017-761

Manuscript under review for journal Hydrol. Earth Syst. Sci.

Discussion started: 9 January 2018

(c) Author(s) 2018. CC BY 4.0 License.
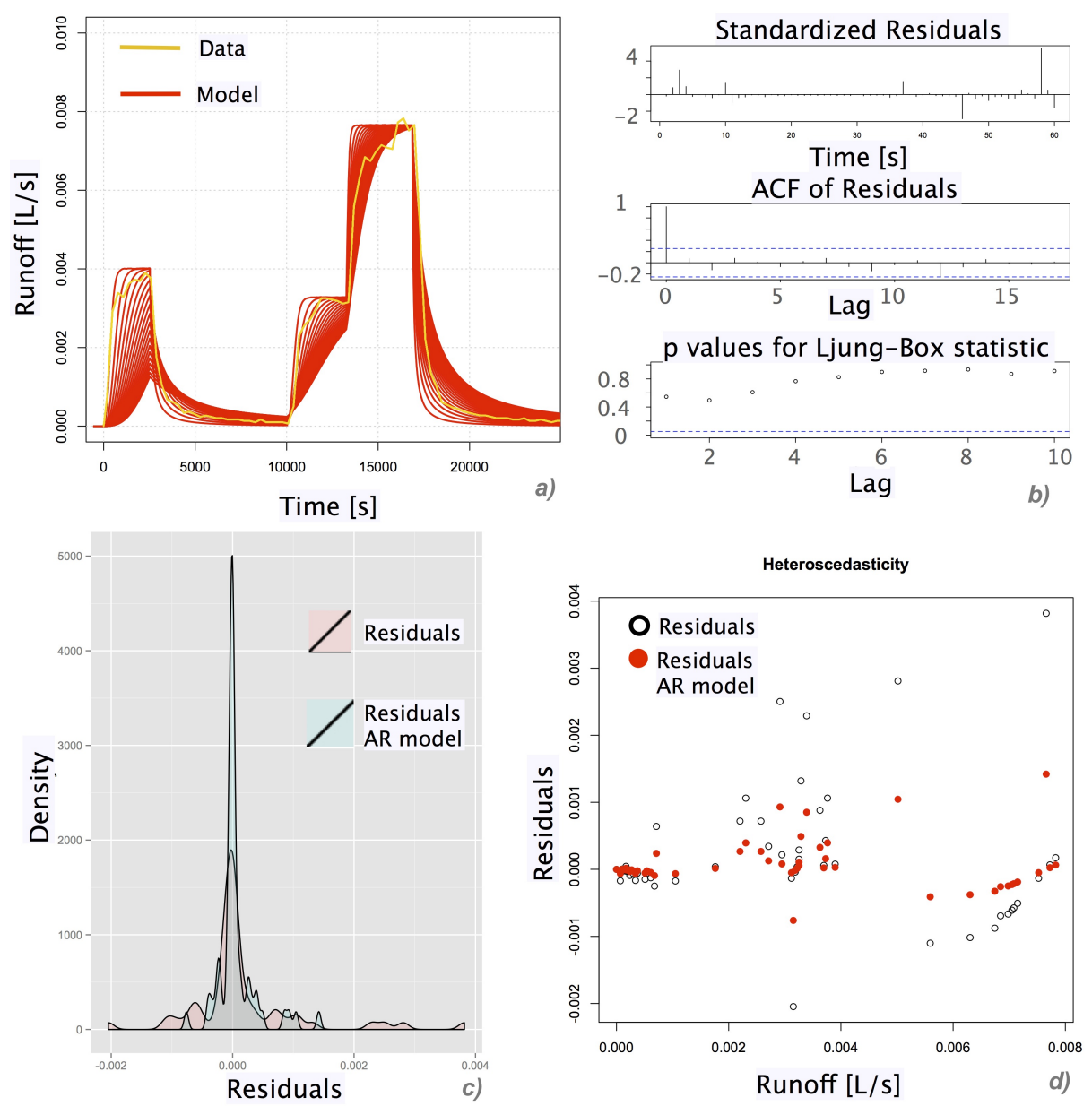

Figure 7. Results of fitting method for profile Fi-11-35, which shows autocorrelation of the first order. a) Runoff data (gold line) compared to model results (red lines) with values of $\mathrm{L}$ between 50 and $1000\left[\mathrm{~m}^{2} \mathrm{~m}^{-3}\right]$. b) results of the ARIMA model. c) Probability density function of the residuals considering autocorelation correction or not. d) Plot for the analysis of heteroscedasticity with autocorrelation-corrected (red dots) and not corrected (black circles) values of residuals.

4. Calculate residuals (model-observation), and use an Autoregressive Model of the first order $(A R(1))$ to consider autocorrelation in the dataset.

5. Autocorrelation is analyzed based on the partial autocorrelation function (PACF) of the residuals and on the LjungBox values (a small value is evidence that there is autocorrelation). The appropriate time lag for the autoregressive model is determined with an extended ARIMA model (ARIMA package of the R.project software).

6. Assess the best fitting value of L using the ordinary least squared approach (OLS).

7. The presence of heteroscedacity in the residuals is analyzed by plotting errors (autocorrelation corrected or not) against the magnitude of the fitted data (in this case runoff). The R-squared of the linear regression is used as index of heteroscedacity. 
Hydrol. Earth Syst. Sci. Discuss., https://doi.org/10.5194/hess-2017-761

Manuscript under review for journal Hydrol. Earth Syst. Sci.

Discussion started: 9 January 2018

(c) Author(s) 2018. CC BY 4.0 License.

(c) (i)
Hydrology and

Earth System

Sciences

Discussions

8. The performance of the model is evaluated using the Nash index, considering both autocorrelated-corrected residuals or not corrected residuals.

For the application of a likelihood approach for the model fitting, different probability distribution function would have been needed to fit the distribution of the residual (e.g. gaussian distribution or generalized gaussian distribution). For this reason

5 OLS resulted to be the most stable approach.

\section{Results}

\subsection{Soil density}

Dry bulk density is an important soil characteristic linked to the hydrological behaviors of a soil profile. Figure 8 shows the soil density distribution in function of soil depth for 183 soil samples analyzed in the study area. Values range between 0.4 and $1.18\left[\mathrm{~g} \mathrm{~cm}^{-3}\right]$ within the first $0.2 \mathrm{~m}$ soil depth, with a mean value of $0.75\left[\mathrm{~g} \mathrm{~cm}^{-3}\right]$. Soil density increases with increasing soil depth down to about $0.6 \mathrm{~m}$ where the values stabilized with a mean value of $1.37\left[\mathrm{~g} \mathrm{~cm}^{-3}\right]$ with a standard deviation of 0.2 . The maximum measured value is $1.77\left[\mathrm{~g} \mathrm{~cm}^{-3}\right.$ ] at $0.85 \mathrm{~m}$ soil depth. The results obtained to the first measurements campaign (P1-18) overlap those obtained from the second campaign (P19-P27).

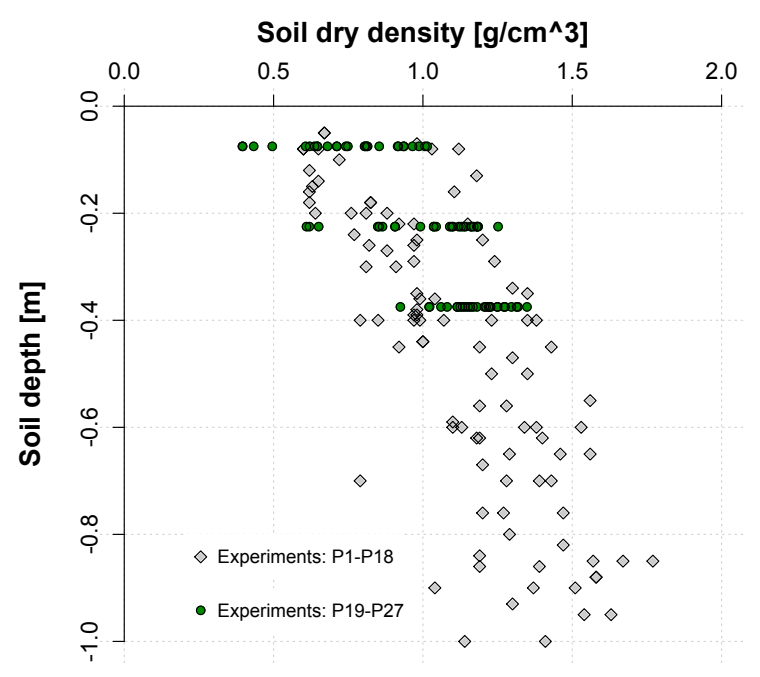

Figure 8. Soil dry bulk density distribution as function of the soil depth.

Figure 9 shows the mean values and standard deviation of measured soil density (a) and soil depth (b) for the 4 defined classes of diagnostic horizons. The highest values of soil density are found in wet or permanent saturated subsoils (horizons class 4) and are significantly different than the other horizons classes. The horizons of class 4 are found at a mean soil depth of 
Hydrol. Earth Syst. Sci. Discuss., https://doi.org/10.5194/hess-2017-761

Manuscript under review for journal Hydrol. Earth Syst. Sci.

Discussion started: 9 January 2018

(c) Author(s) 2018. CC BY 4.0 License.

(c) (i)
Hydrology and

Earth System

Sciences

Discussions

about $0.6 \mathrm{~m}(\mathrm{sd}=0.2)$ and is considered in the study area as the low permeable layer that constrain lateral subsurface flow in the shallow layers of the vadose zone.
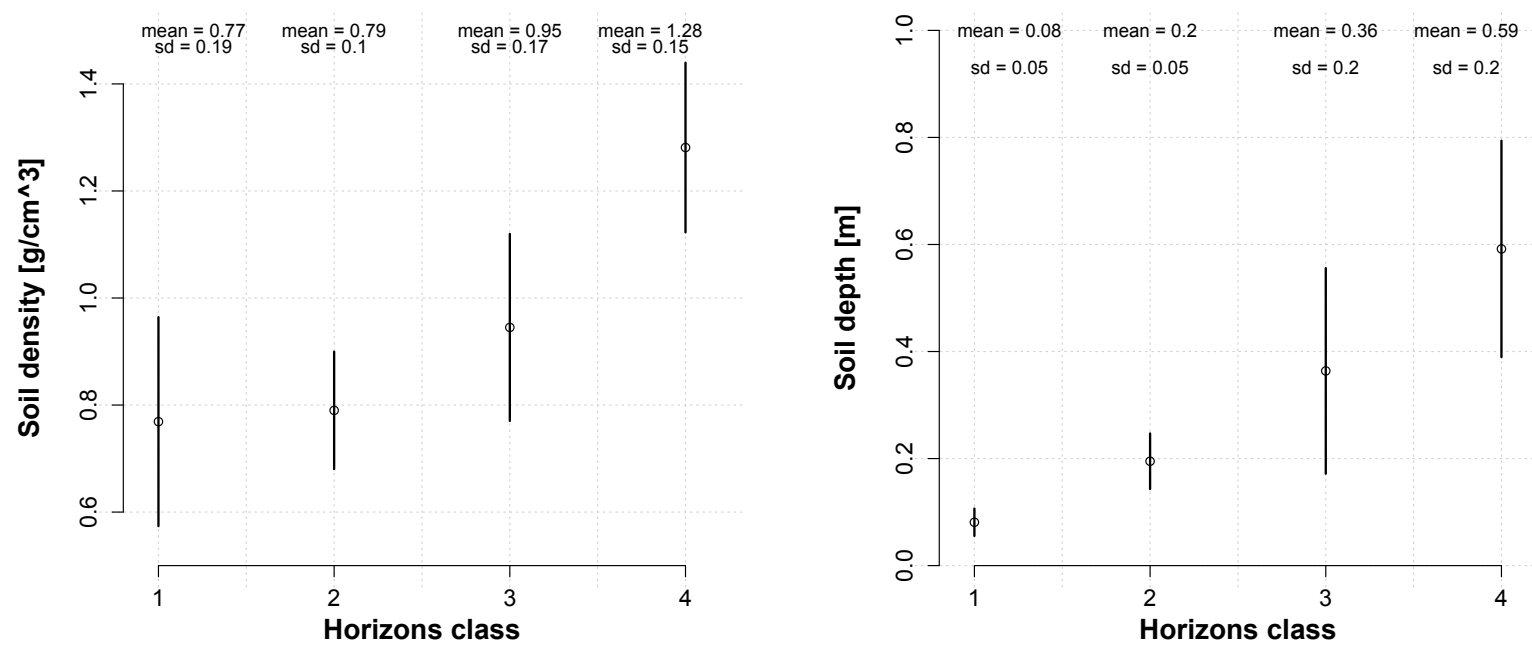

a)

b)

Figure 9. Mean values and standard deviation of soil bulk density and soil depth of each diagnostic horizon class (1 to 4 ).

\subsection{Root distribution}

The root distribution was analyzed for 102 HUMAX probes in term of fine roots length per unit of soil volume for the data of

P1 to P18. Manual count of fine roots frequency was collected for a total of 9 soil profiles with distances from stem ranging from 0.5 to $5.5 \mathrm{~m}$ for the data of P19 to P27. The DBH of tree stems range between 0.14 and $0.49 \mathrm{~m}$. Figure 10 shows the distribution of fine roots in function of distance from tree stem (a) and soil depth (b). The results of the HUMAX probes are shown as total length of fine roots per unit of soil volume, whereas the frequency of the fine roots counted manually is given as number of fine roots per width of soil profile. The mean values of fine roots frequency was $13,18,19,12$, and $10\left[\mathrm{~N}^{\circ} / \mathrm{m}\right]$ at the distance of $0.5,1.5,2.5,3.5$, and $5.5 \mathrm{~m}$ with a standard deviation of $13,17.5,22.3,15.9$, and 11.5 respectively. The frequency of fine roots and total fine roots length decrease with increasing soil depth with similar non-linear behavior. More than $90 \%$ of fine roots result to be constrained in the first $0.6 \mathrm{~m}$ of soil profile.

\subsection{Water content: "long" experiments}

Overall, we recorded 102 time series of water content from 18 "long" sprinkling experiments. The analysis of water content and mobile water content for each single FDR probe from experiment P1 to P18 show an high heterogeneity of behaviors. The data from the third sprinkling of each experiment is considered the most important to study the hydrological behavior of small 
Hydrol. Earth Syst. Sci. Discuss., https://doi.org/10.5194/hess-2017-761

Manuscript under review for journal Hydrol. Earth Syst. Sci.

Discussion started: 9 January 2018

(c) Author(s) 2018. CC BY 4.0 License.

(c) (i)
Hydrology and

Earth System

Sciences

Discussions
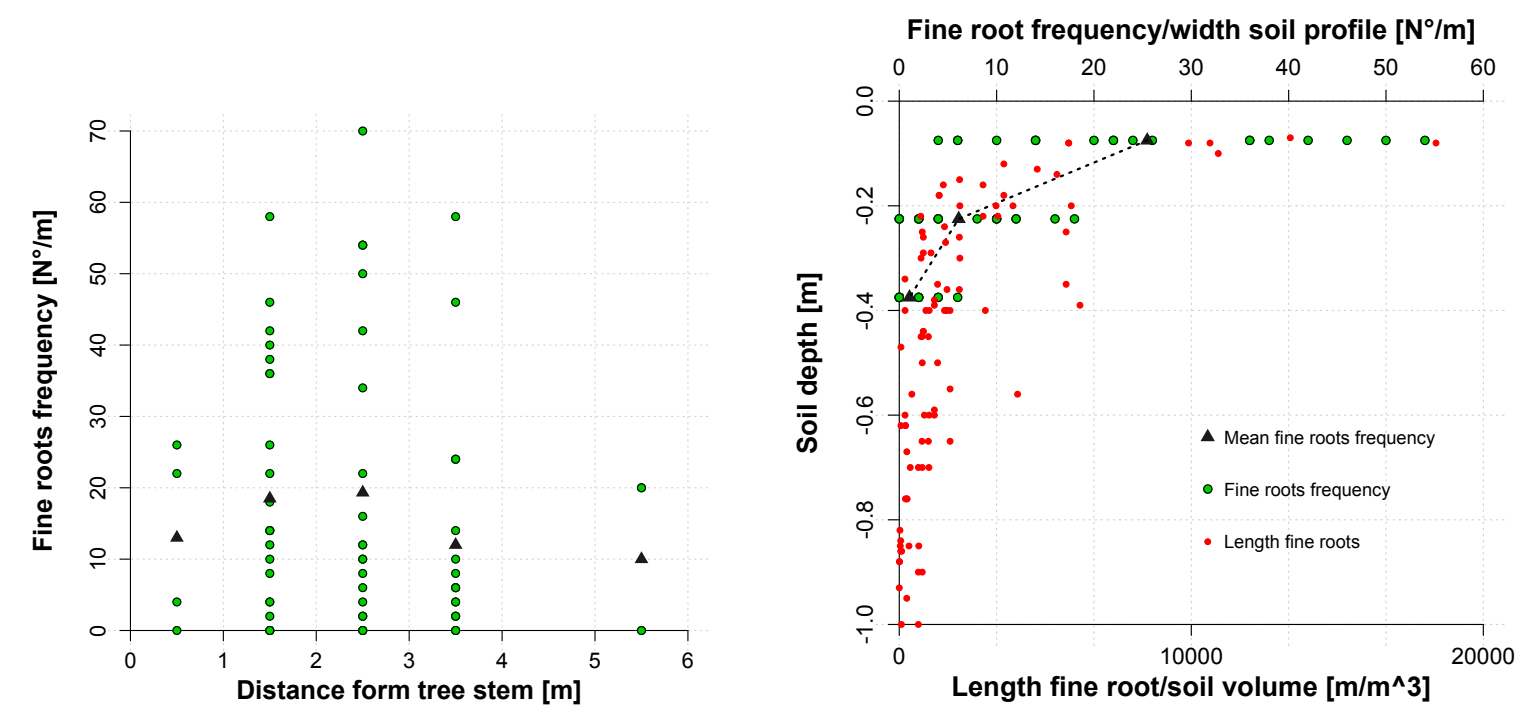

a)

b)

Figure 10. Distribution of measured fine roots (number of fine roots and total length of fine roots) in function of distance from stem and soil depth.

soil volume (about 1 liter), because the variation of mobile water is less influenced by capillarity gradient between meso-pores and soil matrix (Lange et al., 2012).

Figure 11 shows the measured mobile water for all the "long" experiment during the third sprinkling as function of soil depth. Although the data show a trend of a decreasing mobile water with increasing soil depth, the variability within the same soil depth is large. Considering that the application of Stokes flow is limited to relative quick hydrological response (within few hours) with volumetric water content variation of at least 0.01 (Lange et al., 2012), it results that most of the soil volume showing preferential flow is concentrated in the first 0.5-0.6 $\mathrm{m}$ soil depth, with few exceptions.

For modeling purposes, the final water content is an important information that define the condition of volumetric water content for which preferential flow becomes the principal runoff mechanism. Figure 12 shows the distribution of measured mobile water and final volumetric water content in different classes of diagnostic soil horizons. The data show a decreasing trend of values from superficial horizons (class 1 ) to generally more deeper seated horizons (class 4). However, the median values of mobile water range between 0.01 and 0.05 , whereas mean values of final water content range between 0.39 and 0.43 with standard deviations between 0.03 and 0.05 .

The time series of volumetric water content variation for each FDR probes were used to calibrate the parameters of the 15 Stokes flow model. Figure 13 shows the relation between the estimated values of contact area (L) and water film thickness (F) for all the time series showing a value of mobile water higher than 0.01 . More than $90 \%$ of fitted values of water film thickness are higher than the lower limit $\left(10^{-6} \mathrm{~m}\right)$ for the dominance of viscous over capillary flow, and all the values are lower than the 
Hydrol. Earth Syst. Sci. Discuss., https://doi.org/10.5194/hess-2017-761

Manuscript under review for journal Hydrol. Earth Syst. Sci.

Discussion started: 9 January 2018

(c) Author(s) 2018. CC BY 4.0 License.

(c) (i)

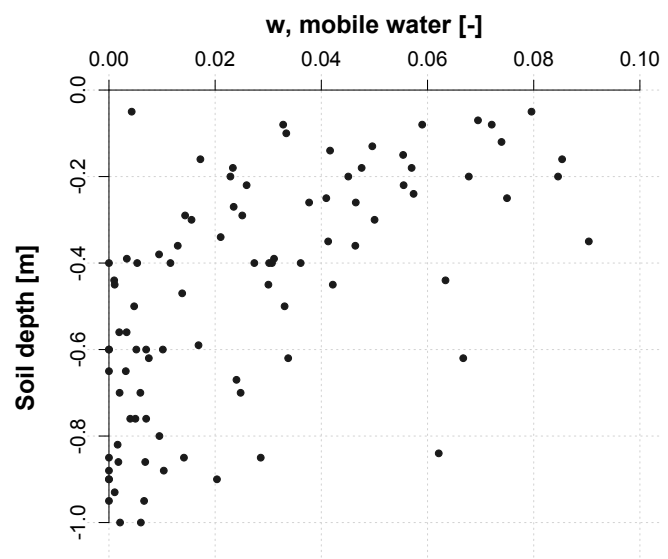

Figure 11. Measured amplitude of mobile water in function of soil depth.
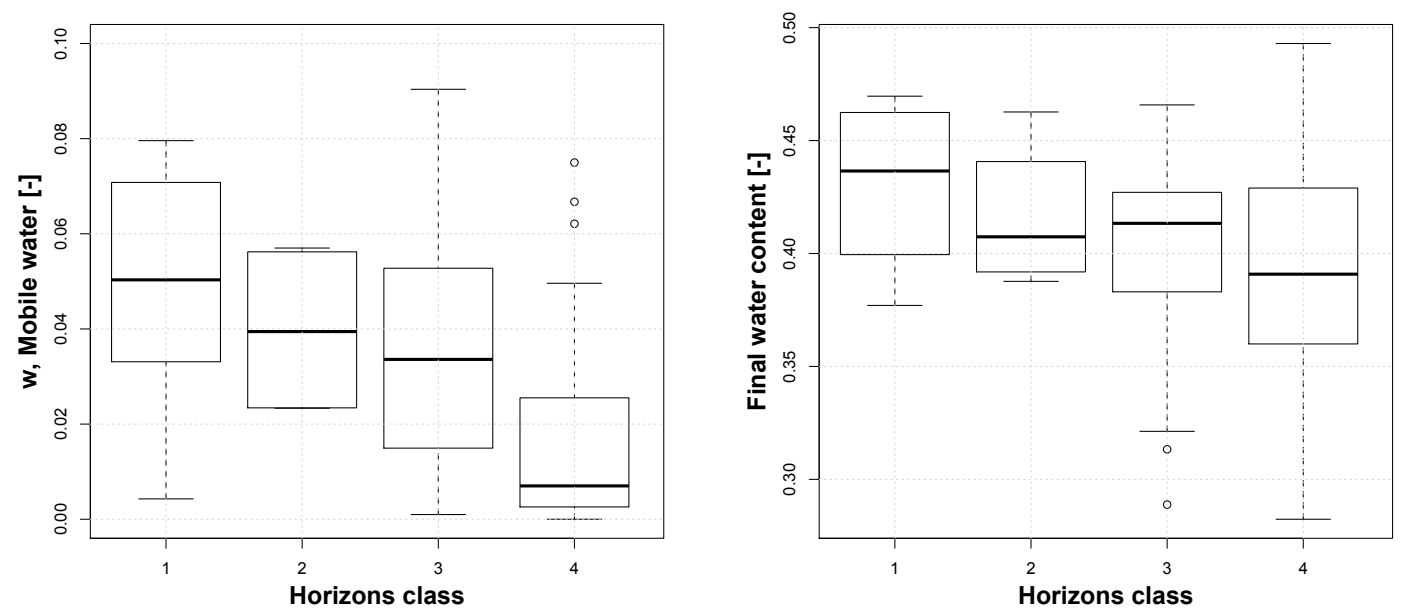

a)

b)

Figure 12. Distribution of measured final water content for each horizons class.

upper limit $\left(10^{-4} \mathrm{~m}\right)$ for non turbulent flow. The definition of the mentioned limits for the application of the Stokes flow are based on the values of water film thickness reviewed in Beven and Germann (2013).

Previous studies have found a relation between the estimated contact length in function total root length of fine roots $(<2$ mm diameter) per soil volume (Lange et al., 2012). Figure 14 shows the relation between contact area and fine roots length per 5 soil volume found in this study. No significant linear regression was found, for this and other measured root parameters. The 
Hydrol. Earth Syst. Sci. Discuss., https://doi.org/10.5194/hess-2017-761

Manuscript under review for journal Hydrol. Earth Syst. Sci.

Discussion started: 9 January 2018

(c) Author(s) 2018. CC BY 4.0 License.

(c) (i)

\section{Hydrology and Earth System Sciences \\ Discussions}

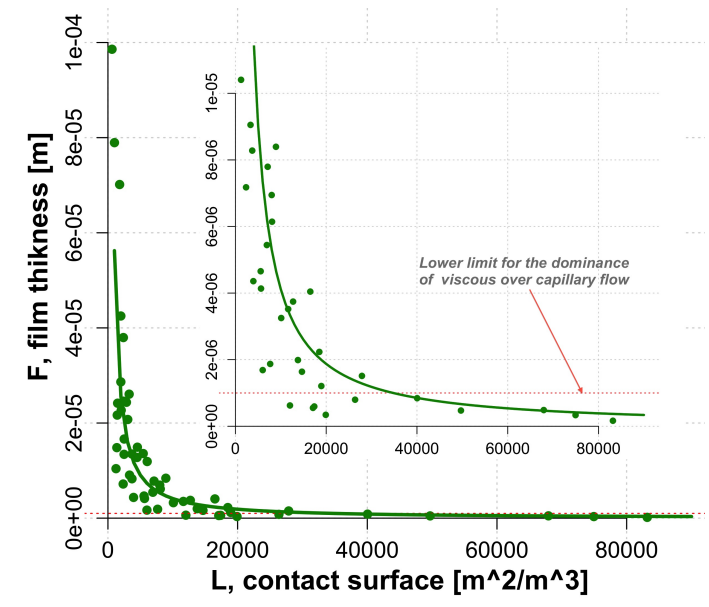

Figure 13. Fitted values of contact area and water film thickness for all time series with mobile water higher than 0.01 . The $p$ value of the non linear regression $\left(F=0.14 L^{-1.13}\right)$ results lower than 0.001 .

data points are concentrated in the lower range of fine roots length and contact area in relation to other studies (Lange et al., 2012).

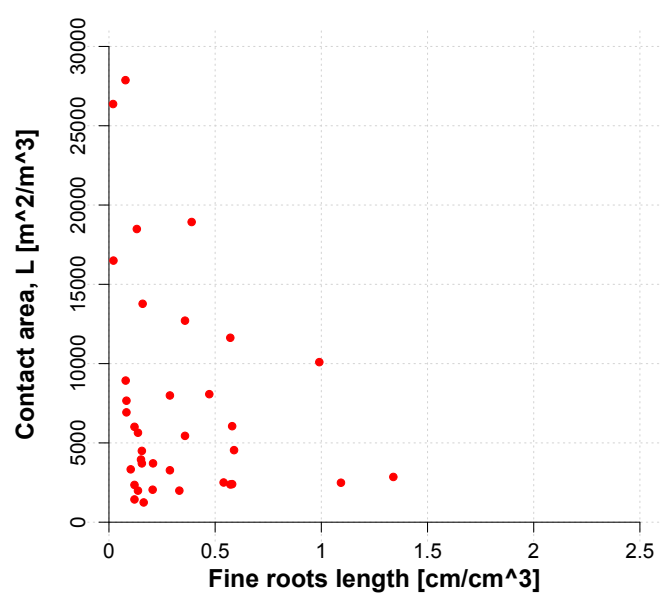

Figure 14. Contact area versus fine roots length per unit soil volume. 
Hydrol. Earth Syst. Sci. Discuss., https://doi.org/10.5194/hess-2017-761

Manuscript under review for journal Hydrol. Earth Syst. Sci.

Discussion started: 9 January 2018

(c) Author(s) 2018. CC BY 4.0 License.

(c) (i)

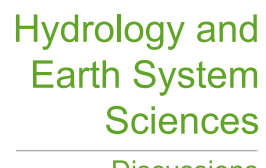

Discussions

\subsection{Water content: "short" experiments}

Overall, we recorded 120 time series of water content from 12 profiles. Only 8 profiles showed significant $(>0.001$ [L/s]) lateral flow within the first $0.45 \mathrm{~m}$ of soil depth, and were used for calibration of the $\mathrm{W}^{2}$ model.

Water content is an important parameter for the characterization of water flow conditions in the soil. The most important values considered from the modeling point of view are the initial water content and the final (residual) water content. Figure 15 shows the distribution of initial water content at different distances form tree stems. Most part of the water content values measured range between 0.25 an 0.35 within the $3.5 \mathrm{~m}$ distances from tree stems (independently form the dimension of the trees), whereas after the sprinkling experiments values range between 0.3 and 0.4 . For the single measurement at 5.5 distance from the stem, higher values of water content before and after the sprinkling were observed. The mean values of increased immobile water $\left(\theta_{\text {fin }}-\theta_{\text {start }}\right)$ measured during the experiments for the first $0.45 \mathrm{~m}$ of soil profile range between 0 and 0.1 .

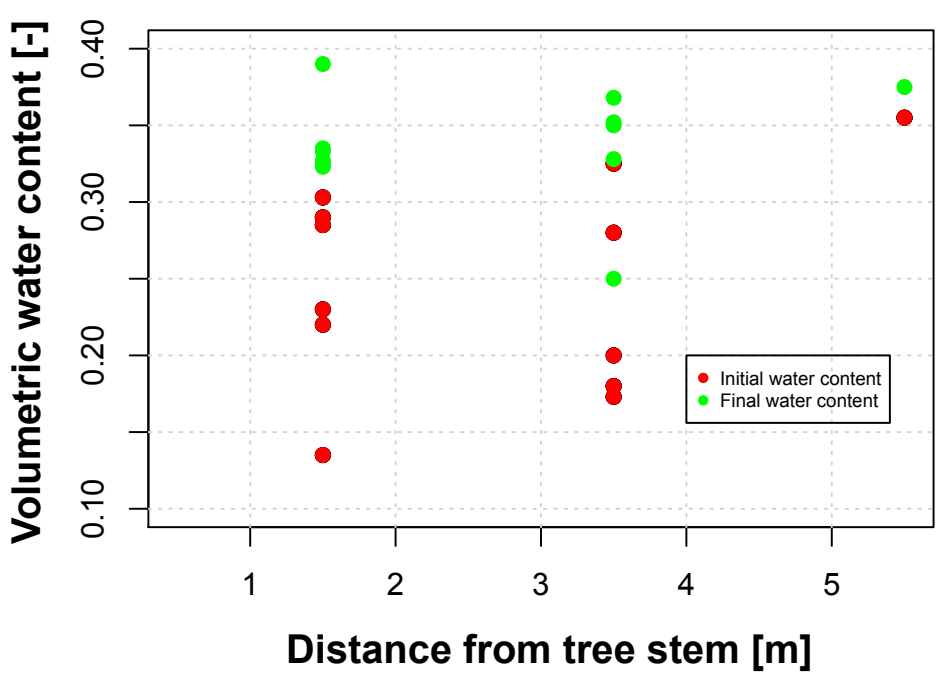

Figure 15. Distribution of initial and final volumetric water content as function of distance from stem. Each point represents the mean value of 10 FDR measurements for each soil profile.

\subsection{Runoff: calibration at soil profile scale}

Lateral runoff is a fundamental information in order to understand the processes involved in the flux and mass balance of water within a soil volume at the pedon scale. The lateral runoff data within the first $0.45 \mathrm{~m}$ of soil depth obtained by the field experiments are use to calibrate two important parameters of the runoff model: the vertical percolation coefficient $c$ and the unit area of momentum dissipation per unit volume $L$. Figure 16 gives an overview of the experiment results and the fitted model 
Hydrol. Earth Syst. Sci. Discuss., https://doi.org/10.5194/hess-2017-761

Manuscript under review for journal Hydrol. Earth Syst. Sci.

Discussion started: 9 January 2018

(c) Author(s) 2018. CC BY 4.0 License.

results obtained minimizing the sum of squared errors considering autocorrelation. During the first hour of the experiment ( $70 \mathrm{~mm} / \mathrm{h}$ rainfall intensity), in 2 of 8 experiments, no lateral runoff was recorded within the first $0.45 \mathrm{~m}$ soil depth. In the experiments where lateral runoff took place during the first sprinkling, only 2 reached quasi steady state conditions. During the third sprinkling experiment, 6 profiles show a quasi steady state runoff. Overall, quasi steady state conditions of lateral runoff results to be proportional to the rainfall intensity.

Fine roots frequency per soil profile width was found to give the best fit to the calibrated values of L. Figure 17 shows the linear and non-linear relation between total fine roots frequency and the calibrated values of $\mathrm{L}$. The values of $\mathrm{L}$ range between 150 and $1950\left[\mathrm{~m}^{2} / \mathrm{m}^{3}\right]$.

The values of the vertical percolation coefficient $c$ have high variability and can range between 0 to almost 1 . No significant relationships were found between $c$ and other parameters such as root distribution or distance from tree stem. The geometric factor $g f$, has a high variability as well, with values ranging between 0 and 1 . The values of $g f$ tend to increase linearly $\left(\mathrm{R}^{2}=0.74, \mathrm{p}<0.001\right)$ with increasing values of estimated maximum water film thickness $F$.

The unit area of momentum dissipation per unit volume $L$ is the most sensible parameter of the model related to the hydrological properties of soil and root distribution. A sensitivity analysis of the model to this parameter for the same sprinkling conditions used during the field experiments is shown in Figure 18. Assuming $c=0, \theta_{0}=0.273$, and $\theta_{\text {fin }}=0.35$ it results that increasing values of $L$, lead to a delayed response of the runoff. The consequence of this delayed response is a lower increase of runoff during short rainfall and a longer persistence of runoff after the end of the rainfall. For short and intense rainfall, the increase of $L$ values, may implicates a considerable reduction of runoff peak values, whereas during longer rainfall when steady state conditions tend to be reached, the magnitude of peak runoff is only related to rainfall intensity and on to $L$.

\subsection{Runoff: theoretical upscaling}

Lateral runoff is a fundamental information in order to understand the processes involved in the fluxes at the hillslope scale. Within the aim of this study, the analysis of the effects that the spatial variation of $L$ has on the hydrological behavior of a vegetated hillslope is of particular interest. In this section we report preliminary results of numerical simulation of runoff behavior of a hillslope considering two different type of vegetation cover structures. Assuming that the major influence of vegetation pattern is related to a different spatial distribution of $L$, and that $L$ can be derived as illustrated in the method section for the position and dimension of the trees, realistic values of $L$ are estimated based on the field experiment results shown in this study. Figure 19 shows an example of preliminary results obtained with the $\mathrm{W}^{2}$ model where two different tree distributions (Fig. 19a and Fig. 19b) are linked to the estimated spatial distribution of $L$ (Fig. 19c, d), and finally implemented in the numerical calculation for the quantification of runoff behaviors during a short and intense rainfall event considering wet (Fig. 19d) and dry (Fig. 19e) pre-event conditions. The rainfall event is assumed to be normal distributed during 1 hour and have a total precipitation of $70 \mathrm{~mm}$. This simple example shows how the presence of higher values of $L$, due to high frequencies of fine roots, considerably delay the hydrological response of a hillslope and how this delay may have considerable consequences on the magnitude and timing of peak runoff, depending on the pre-event moisture conditions. The partial runoff coefficient 
Hydrol. Earth Syst. Sci. Discuss., https://doi.org/10.5194/hess-2017-761

Manuscript under review for journal Hydrol. Earth Syst. Sci.

Discussion started: 9 January 2018
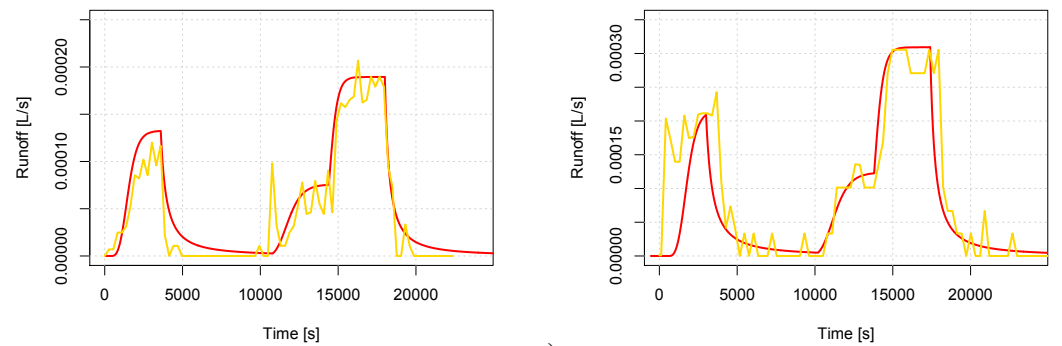

a)

b)
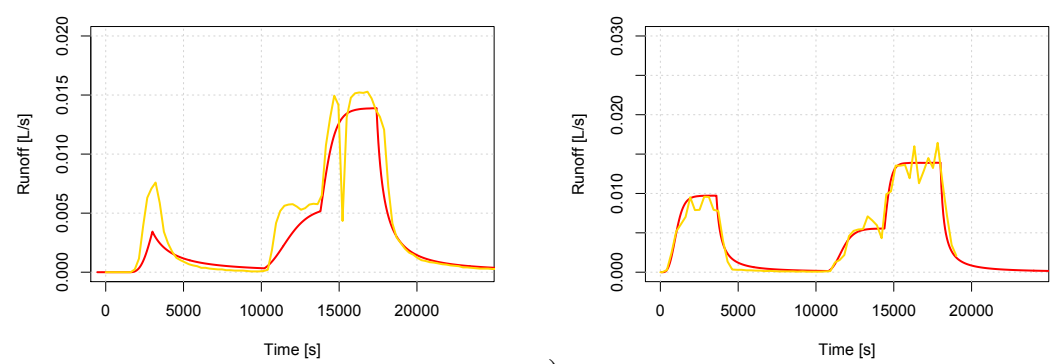

c)

d)
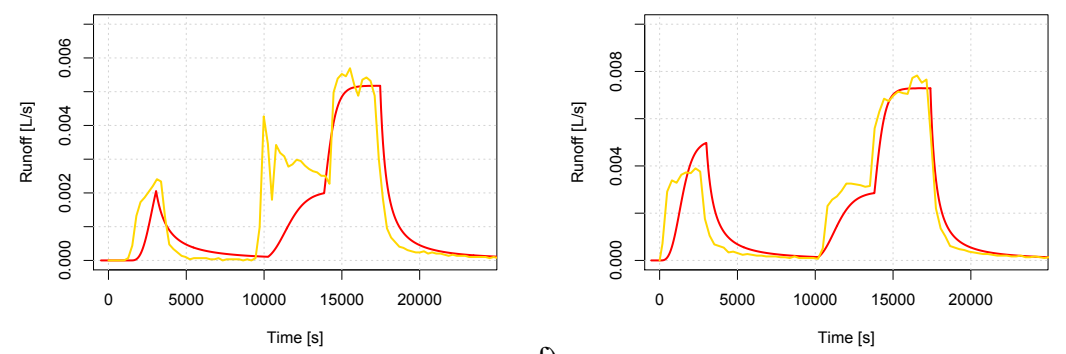

f)

g)
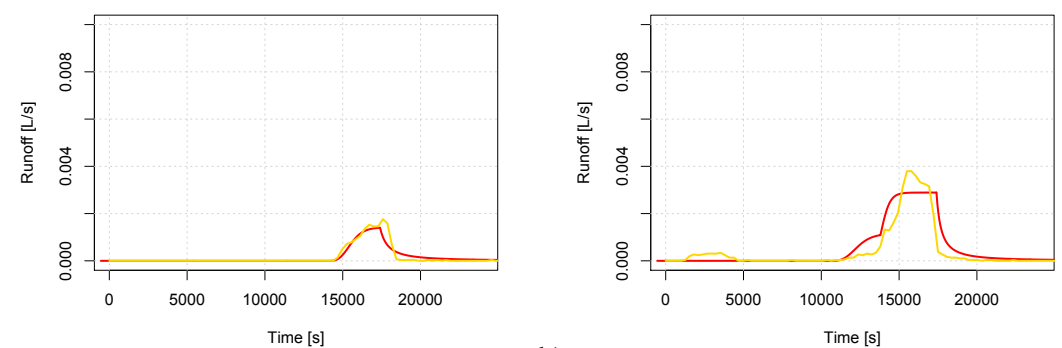

h)

i)

Figure 16. Measured (yellow) and modeled (red) lateral runoff [L/s] of experiment near spruce trees. Plots a-c-f-h are from profiles at $1.5 \mathrm{~m}$ distance, plots b-g-i are from 3.5 distance, and plot d from 5.5 distance from stem. 
Hydrol. Earth Syst. Sci. Discuss., https://doi.org/10.5194/hess-2017-761

Manuscript under review for journal Hydrol. Earth Syst. Sci.

Discussion started: 9 January 2018

(c) Author(s) 2018. CC BY 4.0 License.

(c) (i)

\section{Hydrology and Earth System Sciences \\ Discussions}

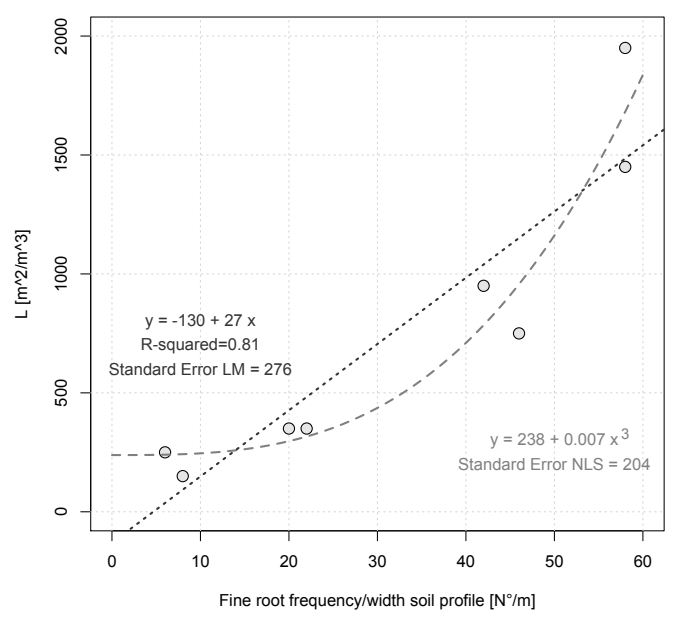

Figure 17. Relation between $\mathrm{L}$ and sum of root circumferences for spruce trees.

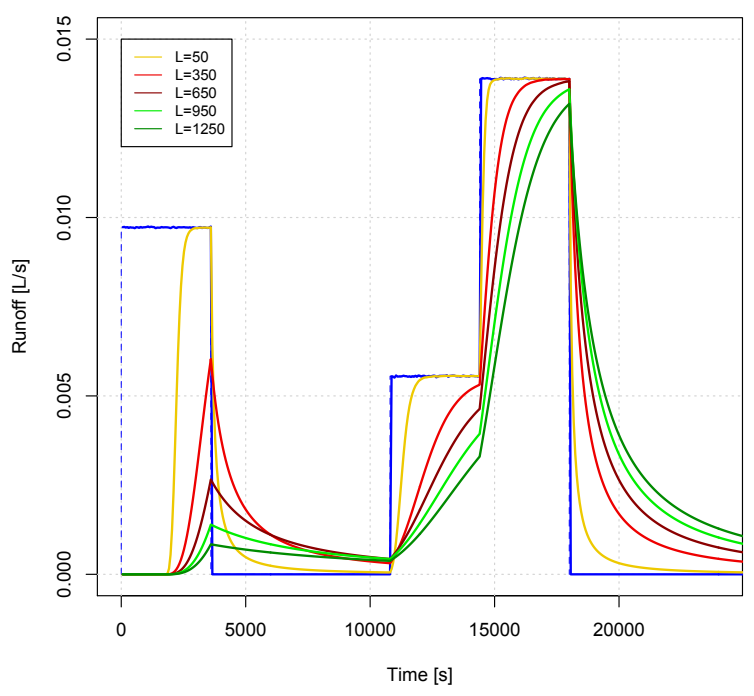

Figure 18. Example of sensitivity of the lateral preferential flow model as function of the parameter $L$. Other parameter are keep constant: $c=0, \theta_{0}=0.273$, and $\theta_{\text {fin }}=0.35$. The blue line represents the rainfall input. Modified from Schwarz et al. (2013).

is assumed to be in all cases equal to 1 (no vertical percolation), in order to emphasise the role of moment dissipation and storage capacity on the runoff behavior. It is important to notice that the reduction of peak flow due to the delayed hydrological response may be present only for short and intense rainfall, whereas during the long rainfall event this effect may go lost. 
Hydrol. Earth Syst. Sci. Discuss., https://doi.org/10.5194/hess-2017-761

Manuscript under review for journal Hydrol. Earth Syst. Sci.

Discussion started: 9 January 2018

Moreover, preliminary analysis show that the time distribution of rainfall (constant, normally distributed or random) may generate completely different type of hydrological response on the same hillslope.

\section{Discussion}

\subsection{Soil horizons, soil density, root distribution and hydromorphic attributes}

5 The distribution of soil horizons classes, soil density, and root distribution as function of soil depth suggest that the soil depth of 0.4-0.6 m represent for all these soil properties a commune threshold in the chosen study area. The local variability of each those soil properties could possibly be explain by topography and root distribution, as found in other studies (Lin et al., 2008; Lin, 2012). In particular the presence of roots may accentuate the spatial heterogeneity of soil physical properties such as soil density and water retention capacity (Wahren et al., 2012; Milleret et al., 2009). The results indicate that the qualitative evaluation of soil properties based on the classification of diagnostic horizons, as intended in hydropedology, is a useful approach for a first estimation of soil hydrological properties during field survey and modeling purpose. For instance, soil structure and hydromorphic attributes could be considered good indicators for the estimation of quantitative parameters such as soil density and mobile water $(w)$ in the field. In the following section we discuss the possibility to use the characterization of diagnostic horizons as indicator for other important parameters such as percolation coefficient $(c)$ and contact ares $(L)$, implemented with a stochastic approach.

The distribution of fine roots in the horizontal and vertical sense are in agreement with the results of previous studies (Arp et al., 1992; Lange et al., 2012), confirming the high heterogeneity of root distribution at the hillslope scale and its relation to forest structure (in term of position and dimensions of trees). The possibility to derive the spatial distribution of roots from remote sensed data, represents a key point for the development of models in several scientific area, that explicitly want implement vegetation effects quantitatively (Schwarz et al., 2012). In the analysis of the root distribution of the "long" sprinkling experiments no distinction between different tree species was done. As discussed in Germann et al. (2012), distribution of horizons groups reflect the vertical distribution of root distribution as consequence of a dynamic iterative interaction between soil processes and root growth. In view of a holistic concept of soil architecture, the analysis of hydrological and pedological data in this study show quantitatively the link between pedological properties and flow processes.

\subsection{Single probes hydrological behavior - water content variation}

The values of soil water content measured during the "long" field experiments in each FDR probe are comparable with the data of other studies under similar simulation conditions (Lange et al., 2009). In particular, the values of soil water content before and after the experiments are similar to other literature values for similar soils under vegetation cover (Scherrer et al., 2007).

The vertical distribution of mobile water within the soil profiles and the related estimated values of water film thickness (figure 12 and 13) indicate that water fluxes during intense rainfall is dominated by preferential flow, especially in the upper $0.6 \mathrm{~m}$ of soil depth. Overall, it is important to notice that the amount of mobile water results in most cases a small part 
Hydrol. Earth Syst. Sci. Discuss., https://doi.org/10.5194/hess-2017-761

Manuscript under review for journal Hydrol. Earth Syst. Sci.

Discussion started: 9 January 2018

(c) Author(s) 2018. CC BY 4.0 License.

compared to the total water contained in a small soil volume (1 to $10 \%$ ), whereas values of water content before and after a rainfall event are considerably larger (from $10 \%$ up to 50\%). Moreover, the time gap between beginning of rainfall and the appearance of preferential runoff, support the hypothesis that a complex range of water mixing issues occur from plotscale vertical infiltration to lateral flow at the hillslope scale (Klaus et al., 2013), in which biological activity (i.e. earthworms and fungi) play an important role. The hypothesis of the mixing processes are a possible explication of "old water paradox". Kienzler and Neaf (2008) conclude in their work that the fraction of pre-event water in the subsurface flow differs between sites, and they explain those differences by the quick or delayed hydrological responses of the hillslope. In the context of this study, it is plausible to assume that the magnitude of the mixing effect of old and irrigation water could be related to the contact area of momentum dissipation $L$, that also determinate the timing of the hydrological response of a hillslope. We found a strong correlation between measured value of mobile water $(w)$ and the estimated values of $L$ and $F$ for a irrigation intensity of 70 $[\mathrm{mm} / \mathrm{h}]$. Calculation of the volume flux density in this study, in agreement with Germann et al. (2012), suggest that preferential lateral flow is characterized by values of $L$ lower than $10^{4}$ for $g f$ near to 1 . For values of $g f$ lower than 1 , meaning an efficient draining network of pores (not tortuous, continuously connected and cylindrical cross section), the value of $L$ for preferential flow may reach values of $4-510^{4}$. The relation found in figure 13 suggest that $L$ not only can be considered as indicator of the soil porosity, but also it could be an indicator of mean pore dimension and geometry. The estimated value of L and $\mathrm{F}$ shown in figure 12 result to be consistent with the assumption of the stoke-flow approach, as discussed in Beven and Germann (2013). The application of the model at limit conditions for the Stokes flow assumptions may be considered tolerable in view of the modeled processes. In fact, high values of $L$ result in low volume flux that is neglectable in term of subsurface flow, enhancing saturated overland flow or approaching the equivalent value of $\mathrm{k}_{s}$ in the case of vertical infiltration. On the other hand, effect of turbulences for low value of $L$ and high values of $F$ lead to conservative estimation of runoff.

The non correlation of root length distribution with hydrological parameter (such as $L$ ) shown in figure 14, could be explained by a scale discontinuity of processes. We observed that within the same soil horizons fine root distribution and preferential runoff features are highly heterogeneous and not directly correlated. Only funneling effects due to coarse roots were evident, in some cases. At the scale of single FDR probe, the spatial variation of fine roots is not related to the spatial variation of hydrological characteristics because the complex interaction of processes that take place over larger scales $(>0.1 \mathrm{~m})$.

\subsection{Soil profile hydrological behavior - water content and runoff behaviors}

The results of the runoff experiment show an high variability in term of total lateral vs. vertical runoff and on the temporal delay of the runoff curve. The results are comparable with previous studies where lateral runoff was dominated by overland flow or subsurface preferential flow (Scherrer et al., 2007; Kohl, 2002). Since this type of results are unique in our knowledge, it is difficult to make comparison with previous studies. Most part of the studies on lateral runoff were conducted at the hillslope scale (Jost, 2012), mostly considering only overland flow (Kohl, 2002). The values of final water content $\theta_{f i n}$ measured during the "short" sprinkling experiments are comparable to the values measured during the "long" sprinkling experiments, indicating that the final condition for lateral preferential flow are comparable between the two type of experiments. In contrast, the values of $L$ estimated for the entire profile using the "short" sprinkling experiments result lower than the values of figure 13 , indicating 
Hydrol. Earth Syst. Sci. Discuss., https://doi.org/10.5194/hess-2017-761

Manuscript under review for journal Hydrol. Earth Syst. Sci.

Discussion started: 9 January 2018

(c) Author(s) 2018. CC BY 4.0 License.

enhanced preferential flow. This values of $L$ and $F$ are difficult to compare to previous studies (Lange et al., 2012) because different approaches and datasets were used for calibration.

The temporal variation of measured water content and runoff during the "short" sprinkling experiments suggest a linear dependency to sprinkling intensity $(70,40$, and $100 \mathrm{~mm} / \mathrm{h})$. This observation suggests that soil saturation was never reach, and that mobile water content is dependent to rainfall intensity under unsaturated condition even if runoff reached in some cases steady state at a constant sprinkling intensity. The capability of the model to depict this dependency is an indication that the physical concepts adopted in the framework are plausible for these type of study sides. During the first hour of the "short" experiments $(70 \mathrm{~mm} / \mathrm{h}$ intensity), rarely runoff steady state was reached. This fact may be explained by two major controlling factors: 1) pre-event moisture condition influencing storage capacity, and 2) momentum dissipation of flow due to $L$. While the first factor is more discussed in literature (Uchida et al., 2005), the second one is usually less commented and represents one of the main outcome of this study. In particular, the delaying effect that momentum dissipation has on the runoff due to the contact area $L$ plays a potential important role in reducing flood peaks in small catchments, depending on the timing and distribution of rainfall. The sensitivity analysis of the model shown in figure 18 emphasize this aspect. This modeling approach allows a coherent framework for the analysis of data showing this mechanisms at the hillslope scale (Kohl, 2002; Jost, 2012).

A limitation of the used field setup was the possibility to measure runoff only within the first $0.45 \mathrm{~m}$ depth. On one side, the fixed setup allows for a better comparison of results between the different data and ensure the characterization of the hydrological behavior of the rooting zone, but on the other side it was not possible to pick up lateral runoff that could may occurred (as observed in same cases) just few centimeter below the lower collecting rill. For those last cases of experiment the data could not be used for the calibration of the model.

From the field observation during the sprinkling experiments, we found that preferential flow took place in both physically (shrinking cracking) and biologically (earthworms burrows, roots channels, fungi-aggregates complex) formed features. Field observations also suggest that macro pores storage within cracks in clay dominated horizons with low biological activity have a high dynamics of hydrological responses switching between delayed runoff in dry condition to quick superficial runoff in wet condition, as observed by others in similar conditions (Jost, 2012); whereas well aggregated horizons due to the presence of roots, fungi and microorganisms have a more stable structure that ensure similar hydrological responses of an horizons for a wide range of soil moisture conditions. As suggested by Brandy and Weil (2008), soils with stable granular structure conduct water much more rapidly than do those with unstable structural units, which break down upon being wetted and may lead to excess overland flow.

The relation found between the fine root distribution of spruce (Picea abies) and the fitted values of $L$ at the soil profile scale represent one of the major experimental results of this paper. This result in part support the assumptions of the modeling framework presented in this study. The results suggest that this is a feasible approach to characterize the link between ecology, pedology and hydrology in a quantitative way, which create a good base for the upscaling eco-hydrological processes from the soil profile scale to the hillslope scale.

The modeled values of volumetric water content result to do not pick up really well the mean measured behavior of the measured VWC variation. In fact, the magnitude of the mobile water measured and the shape of the draining front behavior 
Hydrol. Earth Syst. Sci. Discuss., https://doi.org/10.5194/hess-2017-761

Manuscript under review for journal Hydrol. Earth Syst. Sci.

Discussion started: 9 January 2018

(c) Author(s) 2018. CC BY 4.0 License.

suggest that the type of processes taking place nearby the runoff collecting rills are quite different that those in the central part of the profile. In a way it is plausible to argue that the data on lateral runoff should be considered more representative of the hydrological behavior of the soil profile within the first $0.45 \mathrm{~m}$ depth, since this is the results of the integrated hydrological response, where as the measurement of the FDR probes are representative only for small soil volumes positioned on the side of the collecting rills. Thus, boundary condition may have influenced these measurements. The total surface monitored by the FRD corresponds to circa $0.1\left[\mathrm{~m}^{2}\right]$ compared to the runoff collecting area of $0.225\left[\mathrm{~m}^{2}\right]$ over a total analysed profile surface of $0.5\left[\mathrm{~m}^{2}\right]$. We did not insert the FDR probes within the runoff collected area in order to avoid alteration of preferential flow due to the funneling effects.

\subsection{Modeling approach}

We started from a physical based model, the Stokes flow, to derive a conceptual-empirical framework that quantitatively link the variation of water content and root distribution with the runoff behavior of a vegetated slope. The empirical parameter that was introduced to resume the complexity of preferential flow characteristic at the pore scale (pores shapes, pore tortuosity, pore connectivity) is the empirical estimated geometrical factor $g f$. The introduction of this coefficient is adopted in order to combine the measured runoff behaviors with the measured variation of volumetric water content. Preliminary analysis show that the value of $g f$ results directly proportional to volumetric water content with values ranging between 0.1 and 1 . This relation is plausible assuming a non-self-similar complexity of a meso- and macro- pore cross section (increasing complexity with decreasing spatial scale). The increase of water content and thus of water film thickness induces an increase of the momentum dissipation effect on the laminar flow. The strong simplification introducing the geometrical factor has different physical meaning, but is in our view is the best compromise between an over-parametrisation of the model and practicability of the model.

In fact, the physical concepts adopted in this work (laminar flow on an inclined plane calculated with the Stokes equation), are a strong simplification of complex real soil structures and this aspect need to be taken in account. In view of the results of this work, we think that the application of the stoke's approach gives in first instance the possibility, with a minimum of parametrization, to link first order pedological and ecological characteristics of the a soil profile to its hydrological properties. Although, in the model is assumed that $L$ its constant and $F$ increase with increasing soil water content, it must be considered that in the reality a more complicated interaction of these two factors determine the runoff behavior. For instance, in some cases the increase of water content lead to the activation of new preferential flow paths (and thus theoretical to an increase of the $L$ ), whereas in other cases, during the welding of cracks, the value of $L$ may decrease. The results of the runoff measurements suggest that the assumption of a constant value of $L$ pick up the dominating processes resulting in a good agreement between relative changes in water content and variation of runoff, also between different rainfall intensities.

In the case of hydrological properties related to the shrinking and welding of cracks in clay unstable horizons, we may considered that in certain conditions these features are continuously connected only superficially and thus work more as "crack storage" than preferential lateral flow paths, and we can assume that the estimation of $L$ is not influenced by such features. moreover, this may have more influence on the threshold value of $\theta_{\text {fin }}$. 
Hydrol. Earth Syst. Sci. Discuss., https://doi.org/10.5194/hess-2017-761

Manuscript under review for journal Hydrol. Earth Syst. Sci.

Discussion started: 9 January 2018

(c) Author(s) 2018. CC BY 4.0 License.

The relation of fine root distribution and $L$ is the most important link between vegetation patterns and hydrological properties present in the $\mathrm{W}^{2}$ model. Even if the results of figure 17 suggest a exponential increase of $L$ with increasing values of fine root density, it should be considered that in same cases root density may reach a maximum threshold determined by physiological limits (Schwarz et al., 2010).

The balance between vertical percolation and lateral subsurface flow in the presented model is defined by a coefficient $c$ which is related to the vertical saturated permeability of the soil profile. Because local variation on vertical soil permeability have a considerable impact on the modeling results, it may be spatially high heterogeneous, and it is more difficult to be characterized than other parameters in the field. This coefficient seem to be one of the model parameters in which spatial and temporal variability could be implemented in the model using a stochastic approach (Beven, 2012).

\subsection{Upscaling framework}

The modeling framework and the data presented in this study try to link the hydrological behavior of forest soil to root distribution at different scale ranging form the single FDR probe $(0.1 \mathrm{~m})$ to soil profile scale $(1 \mathrm{~m})$, exploring numerically the behaviors at the hillslope scale (10-100 m). The plausibility of numerical simulation results at the hillslope scale are supported by data as reported by Kohl (2002) and Jost (2012), that clearly show the difference in increase of runoff quantity depending on the vegetation cover. The results of the present work can explain such experimental results as the effect of the spatial variability of fine roots distribution linked to the contact area of momentum dissipation $L$, as shown in figure 19.

As mentioned in Germann et al. (2012), thin $F$ and large $L$ means dispersed flow in a great number of diffusive voids as in a well structured A horizon. In contrast, thick $F$ and short $L$ indicate relatively few flow paths along distinct channels (i.e. funneling effect). In the $\mathrm{W}^{2}$ model, funneling effects due to big roots, as documented by Schwärzel et al. (2012), are 20 comparable locally to shallow subsurface preferential flow (SSF1). Big roots, pipes, and Macropores are rarely connected for long distances (couple of $\mathrm{dm}$ ), and the regime of preferential flow in forest soils seems to be dictated by the characteristics of mesopores $(0.05-2 \mathrm{~mm}$ ) geometry and connectivity. This observation is in agreement with other studies where preferential flow seems to occur even when macropores are not directly connected (Nieber and Sidle, 2010).

The proposed upscaling framework combines quantitative methods for the spatial characterization of hydrological parameters related to vegetation patterns with stochastic parametrization of processes within a percolation theory concept. In particular, the present study shows how the characterization of vegetation and micro-topography (quantifiable with remote sensing methods such as LiDAR of stereo-analysis), can be used to link and extrapolate underground pedological and hydrological parameters which are otherwise difficult to be systematically quantified at small spatial and temporal scales.

The preliminary results of the numerical simulation at the hillslope scale suggest that pre-event soil moisture, hydrological connectivity and flow momentum dissipation are important aspect in controlling hillslope runoff during intense rainfall. The sensitivity analysis of the calibrated model, considering realistic boundary conditions, shows that variations of the unit area of momentum dissipation per unit volume $L$ lead to important changes in the runoff behavior of a soil profile (figure 12). In particular, without changes in soil moisture storage capacity it is shown how time delaying effects due to the viscous dissipation of forces along the contact area between the liquid and solid phase reduce the peaks of runoff under different conditions of 
Hydrol. Earth Syst. Sci. Discuss., https://doi.org/10.5194/hess-2017-761

rainfall intensity and initial conditions of soil water content. Thus, at the single profile scale, it can be concluded that even without any changes of water storage capacity, an increased density of roots lead to a mitigation of runoff peak. The magnitude of this effect, however, depends on the initial condition of soil water content and rainfall(-input) intensity. Upscaling these mechanisms from the soil profile scale to the hillslope scale implicate the characterization of the slope hydrological connectivity in space and time. The model condition for which initiation of lateral preferential flow is threshold dependent controlled by total rainfall amount and the pre-event soil moisture is in agreement with the runoff behavior of other instrumented sites (Uchida et al., 2005; Kohl, 2002). Further studies are needed to validate the proposed upscaling framework and test the sensitivity of the model by numerical experiments (Hopp and McDonnell, 2009). If the validity of the model is confirmed, the capability of the model to pick up considerable difference in hydrological responses due to different vegetation patterns (as shown in figure 19) could have important application for the optimization of protection forest managements. Further extension of the framework should consider self-organization mechanisms of the slope depending on contributing area and topography (Bachmair and Weiler, 2011).

\section{Conclusions}

The experimental and theoretical investigations presented in this study shed light on the impact of root distribution on runoff behavior of forested soil profiles. The preliminary results presented in this paper indicate that the increasing of root distribution (in this case quantified as fine root frequency of spruce trees (Picea abies) would lead to an increase of the unit area of momentum dissipation per unit volume of soil, thus leading to an attenuation of the runoff peak at the $1 \mathrm{~m}$ scale due to runoff delay. It is important to notice that even if the total amount of runoff would not be influenced by vegetation, the smoothing effect on the runoff curve due to the presence of root is related only on the viscous dissipation of forces and thus through the reduction of flow velocity. On top of the idea of hydropedology (Lin et al., 2008), the analysis of vegetation patterns may increase the potential of using remote sensing information to quantitatively characterize the surface and subsurface runoff processes of vegetated hillslopes. The proposed framework aim to explicitly characterize an element of the landscape heterogeneity (vegetation patterns) in numerical models, and in this way consider processes complexity, in agreement with the vision of McDonnell et al. (2007) about interdisciplinary watershed hydrology.

The first results suggest the plausibility of the proposed approach, but further research at both soil profile and hillslope scale are needed to confirm the applicability of the model and its possible use for the quantification of the influence of silvicultural measures on hydrological processes within the aim of flood protection. However, we emphasize the discussion on the importance that momentum dissipation may have on the mitigation of flood peaks. In view of previous studies at the hillslope scale that show this type of effect (Kohl, 2002; Jost, 2012), the assumption made in the presented molding framework seems to pick up this type of first order mechanisms and factors. Further laboratory and field experiments should be able to strength quantitatively the applicability of the model and asses the incertitude related to the model parametrization.

In view of the present results, the discussion on the protective function of forest against flood should focus on the quantitative differentiation of effects in function of soil type, rainfall duration-intensity, and seasonality (wet or dry rainfall antecedent 
Hydrol. Earth Syst. Sci. Discuss., https://doi.org/10.5194/hess-2017-761

Manuscript under review for journal Hydrol. Earth Syst. Sci.

Discussion started: 9 January 2018

(c) Author(s) 2018. CC BY 4.0 License.

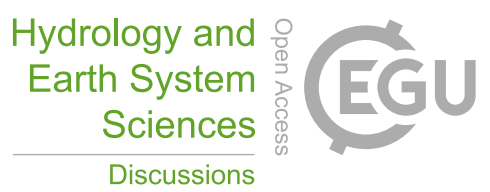

(c) (i)

conditions); as consequence of this conclusion, it is recommended to quantify the protective benefit of the different type of forests with a integral probabilistic approach that considers the cumulative effects on single rainfall events (in term of durationintensity and return time) on a long term period, as conceptualized in Schwarz et al. (2013).

Acknowledgements. We thanks L. Dämple and M. Walser for the immense support during the field work, as well as K. Allenspach and E. 5 Stimm for the data shearing of the "long" sprinkling experiments. 
Hydrol. Earth Syst. Sci. Discuss., https://doi.org/10.5194/hess-2017-761

Manuscript under review for journal Hydrol. Earth Syst. Sci.

Discussion started: 9 January 2018

\section{References}

Arp, P.A., Yin, X.: Predicting water fluxes through forests from monthly precipitation and mean monthly air temperature records, Can. J. Forest Res., 22, 864-877, 1992.

Bachmair, S., Weiler, M.: New Dimensions of Hillslope Hydrology, in: Forest Hydrology and Biogeochemistry, Ecological Studies, 216, 455-481, 2011.

Beven, K.: Rainfall-Runoff Modelling: the primer, Wiley-Blackwell editor, Oxford, 457 pp., 2012.

Beven, K., Germann, P.L.: Macropores and Water Flow in Soils Revisited, Water Resour. Res., 49(6), 3071-3092, doi: 10.1002/wrcr.20156, 2013.

Bogner, C., Gaul, D., Kolb, A., Schmiedinger, I., Huwe, B.: Investigating flow mechanisms in a forest soil by mixed-effects modelling, Eur. J. Soil Sci., 61, 1079-1090, 2010.

Di Pietro, L., Ruy, S., Capowiez, Y.: Predicting preferential water flow in soils by traveling-dispersive waves, J. of Hydrol., 278(1), 64-75, 2003.

Germann, P.F.: Preferential flow and the generation of runoff: 1. Boundary layer flow theory, Water Resour. Res., 26, 3055-3063, 1990.

Germann, P.L., Lange, B., Lüsher, P.: Preferential flow dynamics and plant rooting systems, in: Hydropedology: synergistic integration of soil science and hydrology, Elsevier, Amsterdam, 121-142, 2012.

Hopp, L., McDonnell, J. J.: Connectivity at the hillslope scale: Identifying interactions between storm size, bedrock permeability, slope angle and soil depth, J. of Hydrol., 376(3), 378-391, 2009.

Jost, G., Schume, H., Hager, H., Kohl, G., Kohl, B.: A hillslope scale comparison of tree species influence on soil moisture dynamics and runoff processes during intense rainfall, J. Hydrol., 420, 112-124, doi:10.1016/j.jhydrol.2011.11.057, 2012.

20 Kienzler, P.M., Neaf, F.: Subsurface storm flow formation at different hillslopes and implications for the "old water paradox", Hydrol. Process., 22, 104-116, doi: 10.1002/hyp.6687, 2008.

Klaus, J., Zehe, E., Elsner, M., Kïlls, C., McDonnell, J.J.: Macropore flow of old water revisited: experimental insights from a tile-drained hillslope, Hydrol. Earth Syst. Sci., 17, 103-118, doi:10.5194/hess-17-103-2013, 2013.

Kohl, B., Markart, G., Bauer, W.: Abflussmenge und Sedimentfracht unterschiedlich genutzter Boden-/Vegetations-komplexe bei Starkregen im Sölktal/Steiermark. BFW-Ber, 127, 5-15, 2002.

Lange, B., Lüscher, P., Germann, P.F.: Significance of tree roots for preferential infiltration in stagnic soils, Hydrol. Earth Syst. Sci., 13, 1809-1821, 2009.

Lange, B., Germann, P.F., Lüscher, P.: Greater abundance of Fagus sylvatica in coniferous flood protection forests due to climate change: impact of modified root densities on infiltration, Eur. J. Forest Res., 132(1), 151-163, doi: 10.1007/s10342-012-0664-z, 2012.

30 Lin, H., Brooks, E., McDaniel, P., Boll, J.: Hydropedology and Surface/Subsurface Runoff Processes, in: M. G. Anderson (Editor-in-Chief) Encyclopedia of Hydrologic Sciences. John Wiley \& Sons Ltd., doi: 10.1002/0470848944.hsa306, 2008.

Lin, H.: Understanding Soil Architecture and its functional Manifestation across scales, in: Lyn H. Hydropedology: synergistic integration of soil science and hydrology, Elsevier, Amsterdam, 41-74, 2012.

McDonnell, J.J., Sivapalan, M., Vache, K., Dunn, S., Grant, G., Haggerty, R., Hinz, C., Hooper, R., Kirchner, J., Roderick, M.L., Selker, J., Weiler, M.: Moving beyond heterogeneity and process complexity: A new vision for watershed hydrology, Water Resour. Res., 43, W07301, doi:10.1029/2006WR005467, 2007. 
Hydrol. Earth Syst. Sci. Discuss., https://doi.org/10.5194/hess-2017-761

Manuscript under review for journal Hydrol. Earth Syst. Sci.

Discussion started: 9 January 2018

(c) Author(s) 2018. CC BY 4.0 License.

(c) (i)
Hydrology and

Earth System

Sciences

Discussions

McGlynn, B.L., McDonnell, J.J., Brammer, D.D.: A review of the evolving perceptual model of hillslope flow paths at the Maimai catchments, New Zealand, J. Hydrol., 257, 1-26, 2002.

Milleret, R., Le Bayon, R.C., Gobat, J.M.: Root, mycorrhiza and earthworm interactions: their effects on soil structuring processes, plant and soil nutrient concentration and plant biomass, Plant Soil, 316, 1-12, doi: 10.1007/s11104-008-9753-7, 2009.

5 Nieber, J.L., Sidle, R.C.: How do disconnected macropores in sloping soils facilitate preferential flow?, Hydrol. Process., 24, 1582-1594, 2010.

Or, D., Tuller, M.: Flow in unsaturated fractured porous media: Hydraulic conductivity of rough surfaces, Water Resour. Res., 36(5), 11651177, doi: 10.1029/2000WR900020, 2000.

Scherrer, S., Naef, F., Faeh, A.O., Cordery, I.: Formation of runoff at the hillslope scale during intense precipitation. Hydrol. Earth Syst. Sci., 11, 907-922, 2007.

Schwarz, M., Lehmann, P., Or, D.: Quantifying lateral root reinforcement in steep slopes: from a bundle of roots to tree stands, Earth Surf. Process. Landforms, 35(3), 354-367, doi: 10.1002/esp.1927, 2010.

Schwarz, M., Cohen, D., Or, D.: Spatial characterization of root reinforcement at stand scale: Theory and case study, Geomorphology, 171, 190-200, 2012.

15 Schwarz, M., Dämpfle, L., Lüscher, P., Mösch, P., Tormann, J.J.: Hochwasserschutzwald Gantrisch: der Weg zur quantitativen Methode für die Praxis. Proceedings of "Forum für Wissen", Birmensdorf (CH), 5.11.2013, 107-116, 2013.

Schwärzel, K., Ebermann, S., Schalling, N.: Evidence of double-funneling effect of beech trees by visualization of flow pathways using dye tracer, J. Hydrol., 470, 184-192, 2012.

Sidle, R. C., Noguchi, S., Tsuboyama, Y., Laursen, K.: A conceptual model of preferential flow systems in forested hillslopes: Evidence of self-organization, Hydrol. Process., 15(10), 1675-1692, 2001.

Šimůnek, J., Jarvis, N. J., Van Genuchten, M. T., Gärdenäs, A.: Review and comparison of models for describing non-equilibrium and preferential flow and transport in the vadose zone, J. of hydrol., 272(1), 14-35, 2003.

Topp, G. C., Davis, J. L., Annan, A. P.: Electromagnetic determination of soil water content: Measurements in coaxial transmission lines, Water Resour. Res., 16(3), 574-582, 1980.

25 Uchida, T., Tromp-van Meerveld, I., McDonnell, J.J.: The role of lateral pipe flow in hillslope runoff response: an inter comparison of non-linear hillslope responses, J. Hydrol., 311, 117-133, 2005.

Wahren, A., Schwärzel, K., Feger, K.H.: Potentials and limitations of natural flood retention by forested land in headwater catchments: evidence from experimental and model studies, J. Flood Risk Manag., 5, 321-335, 2012. 
Hydrol. Earth Syst. Sci. Discuss., https://doi.org/10.5194/hess-2017-761

Manuscript under review for journal Hydrol. Earth Syst. Sci.

Discussion started: 9 January 2018
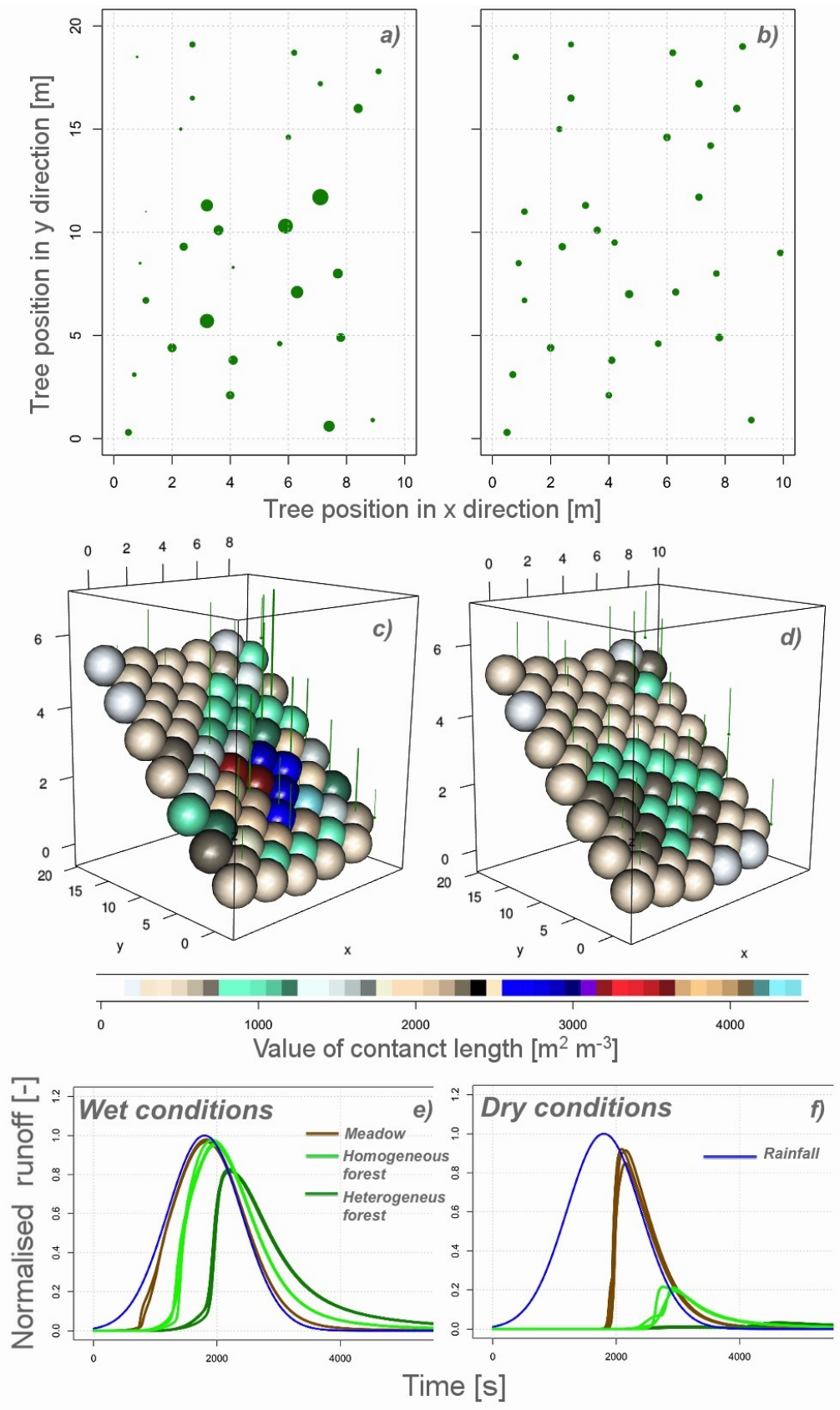

Figure 19. Results of numerical experiment for the characterization of the runoff behaviors at the hillslope scale. $a$ ) heterogeneous forest stand. Circles represent tree size. $b$ ) homogeneous forest stand. $c$ ) spatial distribution of contact length, $L$, for heterogeneous forest stand, and, $d$ ), for homogeneous forest stand. e) runoff behaviors for short and intense rainfall under pre-event wet condition, and, $d$ ), under pre-event dry condition 